\title{
Modelling the energy and exergy utilisation of the Mexican non-domestic sector: A study by climatic regions
}

\author{
Iván García Kerdan,*, David Morillón Gálvez ${ }^{\mathrm{b}}$, Rokia Raslanc, Paul Ruyssevelta \\ a Energy Institute, University College London, 14 Upper Woburn Place, London WC1H ONN, UK \\ b Departamento de Mecánica y Energía, Instituto de Ingeniería, Universidad Nacional Autónoma de \\ México, México \\ c Bartlett School of Graduate Studies, University College London, 14 Upper Woburn Place, London \\ WC1H ONN, UK
}

\section{Abstract}

This paper presents the development of a bottom-up stock model to perform a holistic energy study of the Mexican non-domestic sector. The current energy and exergy flows are shown based on a categorisation by climatic regions with the aim of understanding the impact of local characteristics on regional efficiencies. Due to the limited data currently available, the study is supported by the development of a detailed archetype-based stock model using EnergyPlus as a first law analysis tool combined with an existing exergy analysis method. Twenty-one reference models were created to estimate the electric and gas utilisation in the sector. The results indicate that sectoral energy and exergy annual input are 95.37 PJ and 94.28 PJ respectively. Regional exergy efficiencies were found to be $17.80 \%, 16.56 \%$ and $23.17 \%$ for the hot-dry, hot-humid and temperate climates respectively. The study concludes that significant potential for improvements still exists, especially in the cases of space conditioning, lighting, refrigeration, and cooking where most exergy destructions occur. Additionally, this work highlights that the method used may be further utilized to study the impact of large-scale refurbishments and promote national regulations and standards for sustainable buildings that takes into consideration energy and exergy indicators.

Keywords: Energy analysis, Exergy analysis, Bottom-up model, Stock modelling, Nondomestic sector, Mexico.

\footnotetext{
${ }^{*}$ Corresponding author at: Energy Institute, University College London, United Kingdom. Tel: +44 (0) 7867798730 Research started at: Departamento de Mecánica y Energía, Instituto de Ingeniería, Universidad Nacional Autónoma de México, México

E-mail address: i.kerdan.12@ucl.ac.uk (I. Garcia Kerdan)
} 


\section{Introduction}

The constant development of "middle-income" countries represents a high environmental risk for achieving world sustainability. Emerging markets, mainly represented by the BRICS Group (Brazil, Russia, India, China, and South Africa) and the MITSK Group (Mexico, Indonesia, Turkey and South Korea), are considered to be a main concern in terms of future energy supply security (Asif and Muneer, 2007; Sadorsky, 2009). The current rates of economic development in these countries indicates that increased energy demand at all sectoral levels may therefore represent a threat to achieving global reduction objectives for 2050 (IPCC, 2007). One of the most important sectors in terms of energy use and emissions is the building sector. Worldwide, buildings account for $40 \%$ of the annual primary energy consumption and up to $30 \%$ of all greenhouse gas (GHG) emissions related to energy use (UNEP-SBCI, 2009).

The thermodynamic analyses commonly undertaken to understand the most common processes found in the built environment are still only based on the first law that states that "energy neither can be created nor consumed but only transformed". This represents both a challenge and a limitation to identifying process' inefficiencies for further improvements. The concept of energy efficiency through first law analysis does not provide a real indicator of how a system or a process approaches an ideal state as this only identifies the losses of work and the effective use of a resource. In support of this concept, the second law of thermodynamics states that "every process where energy or matter is dispersed, entropy is inevitably generated". This means that exergy (a measure of quality of energy or useful work potential of energy) can actually be lost as a result of the irreversibilities of a process. An exergy analysis reveals the losses of available energy and thus represents the real inefficiencies of any system. For this reason, the concept of exergy can be essential key method that can be utilized to inform both policy making and national standard design activities (Dincer, 2002).

Initially, exergy analysis was only performed for thermal plants, diesel engines, combined cycle operation, and combustion processes, and it is still a fundamental tool in locating inefficiencies in industrial processes. But building systems operate also as an exergy-entropy process; a building and its systems basically feeds on exergy, consumes exergy, generates entropy and finally the generated entropy is disposed. Disposing of the generated entropy from the system makes new room for feeding 
on new exergy and consuming it again, thus the process cycles (Shukuya, 1994). Even though the Second Law concept is well described in scientific books, engineers and researchers still tend to neglect the use of this principle in the design, test and/or evaluation of thermodynamic systems found in the building sector (Bilgen and Takahashi, 2002; Hepbasli, 2012). Several attempts have been made in the past decade to improve the exergy consumption in buildings, mainly with the development of the International Energy Agency's Energy in Buildings and Communities Programme Annex 37 (ECB-Annex37, 2007) and Annex 49 (ECB-Annex49, 2011). These research efforts, amongst other outcomes, have developed methods and tools for exergy analysis in a steady state reference environment.

While extensive research has been carried out at individual building systems level, to improve the sectors' efficiency, information regarding the exergy baseline of the entire non-domestic sector is still required to provide a complete perspective. Sectoral exergy research, including the non-domestic sector, has been undertaken in the past 20 years in countries such as the U.K., Norway, Turkey, Saudi Arabia, Malaysia, Greece, Japan, U.S., and Canada (Al-Ghandoor, 2013; Dincer et al., 2004; Ertesvåg, 2001; Gasparatos et al., 2009; Hammond and Stapleton, 2001; Kondo, 2009; Reistad Gordon, 1980; Rosen, 2013; Rosen, 1992; Saidur et al., 2007; Utlu and Hepbasli, 2003; Xydis et al., 2009). The majority of these studies approach the sectoral exergy analysis from a top-down econometric approach. The obvious disadvantage of top-down modelling is that it does not have the capability to analyse different conservation measures and perform "what if" scenarios. An alternative to this approach is the bottom up engineering method (EM), which is described by Dineen and Gallachoir (2011) as a model which relies on information on the building characteristics and end uses to calculate the energy consumption based use and equipment characteristics and thermodynamic principles. A significant advantage of engineering bottom-up models over top-down approaches is their ability to model the energy demand of end uses and (new) technologies in detail (Swan and Ugursal, 2009).

Generally, the EM approach involves the development of a database that is representative of the national stock supported by a whole-building energy simulation program to estimate energy consumption (Aydinalp et al., 2003). This technique has strengths such as the ability to model new 
technologies based solely on their technical characteristics. Also, EM is the only method that can fully develop the energy consumption of the sector without the use of any historical energy consumption information; although a main drawback is that occupant behaviour must be assumed (Swan and Ugursal, 2009).

A sectoral analysis represents a higher degree of complexity because of the necessity of illustrate an entire stock in a few representative models. Single building modelling is useful in assessing the performance of a particular building; on the other hand, stock models are essential in informing national and regional policy addressing climate change, energy savings and the reduction of carbon emissions. From a review of related literature in the field, it can be noted that as yet no study on sectoral energy/exergy analysis in Mexico has been developed. In addition, a large gap of data and information about the energy consumption in buildings, especially in the non-domestic sector exists in Mexico. To address this gap, the objective of this study is to provide information of end use energy use data and exergy indicators of the current situation (2014) of the non-domestic sector. These outputs could, in theory, lead to programs focused on energy efficiency under an energetic and exergetic approach. In this study, energy and exergy performance by end use in several climatic regions of Mexico are presented with the aim to analyze the impact of local climate on energy use and exergy destruction of the sector (Dovjak et al., 2010).

\section{Nomenclature}

\begin{tabular}{|lll|}
\hline Symbol & Description & Units \\
$E U I$ & Energy Use Intensity & {$\left[\mathrm{kWh} / \mathrm{m}^{2}\right.$-year $]$} \\
$T O$ & Reference temperature & {$[\mathrm{K}]$} \\
$T p$ & Product temperature & {$[\mathrm{K}]$} \\
$Q p$ & Heat product & {$[\mathrm{J}]$} \\
$W e$ & Work (electric) & {$[\mathrm{J}]$} \\
$C O P$ & Coefficient of Performance & {$[\mathrm{J}] /[\mathrm{J}]$} \\
$\eta$ & Energy efficiency or first law efficiency & {$[\%]$} \\
$\psi$ & Exergy efficiency or second law efficiency & {$[\%]$} \\
\hline
\end{tabular}




\begin{tabular}{|lll|}
\hline qfuel & quality factor of an energy source & {$[-]$} \\
fi & fraction of total utilization of an end-use & {$[\%]$} \\
\hline
\end{tabular}

\section{Case study: Mexico and its non-domestic sector}

Mexico is located between the $32^{\circ}$ and $14^{\circ}$ north latitudes and $86^{\circ}$ and $118^{\circ}$ west longitudes comprising a total surface area of almost 2 million $\mathrm{km}^{2}$. The country has a very diverse climate, where hot climate dominates with several types of sub-climates. Mexico can be divided into a tropical and a temperate zone; but the relief characteristics of the territory together with the large oceans that surround the country it greatly influence the configuration map of the climates. In this study the country has been segregated into 3 main climates: hot-dry, hot-humid and temperate (Fig. 1).

[Fig. 1. about here]

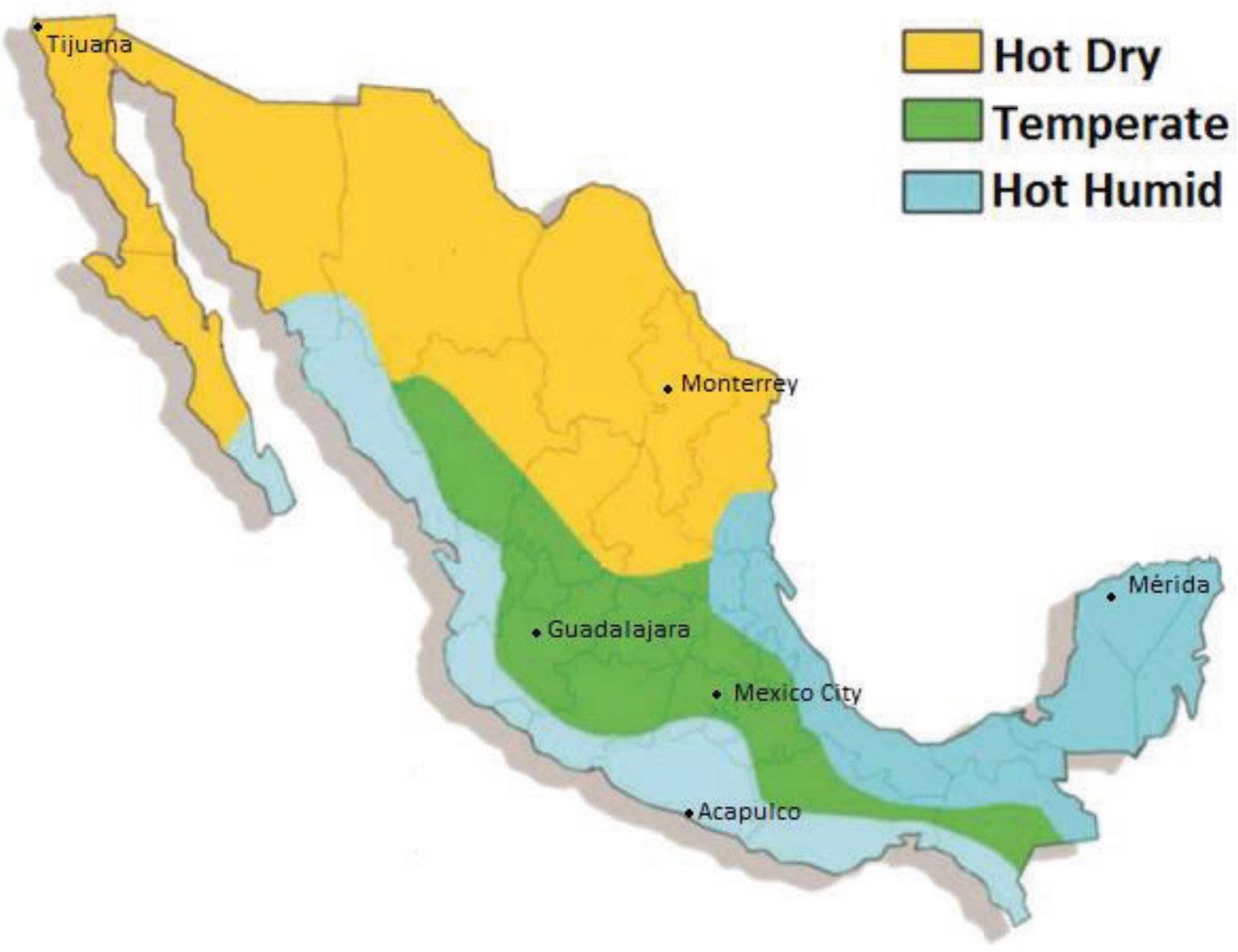

Fig. 1. Main climatic regions in Mexico 
Mexican buildings are responsible for $19 \%$ of the national energy utilization and $12 \%$ of the total emissions of the country (de Buen, 2009). In particular, the consumption of electricity and gas represents $31 \%$ and $38 \%$ respectively of the national consumption. According to the National Energy Balance (SENER, 2013), the "commercial and service" sector mainly uses gas and electricity to meet its end use demands, representing $95 \%$ of the total use of resources in the sector (Fig.2).

[Fig. 2. about here]

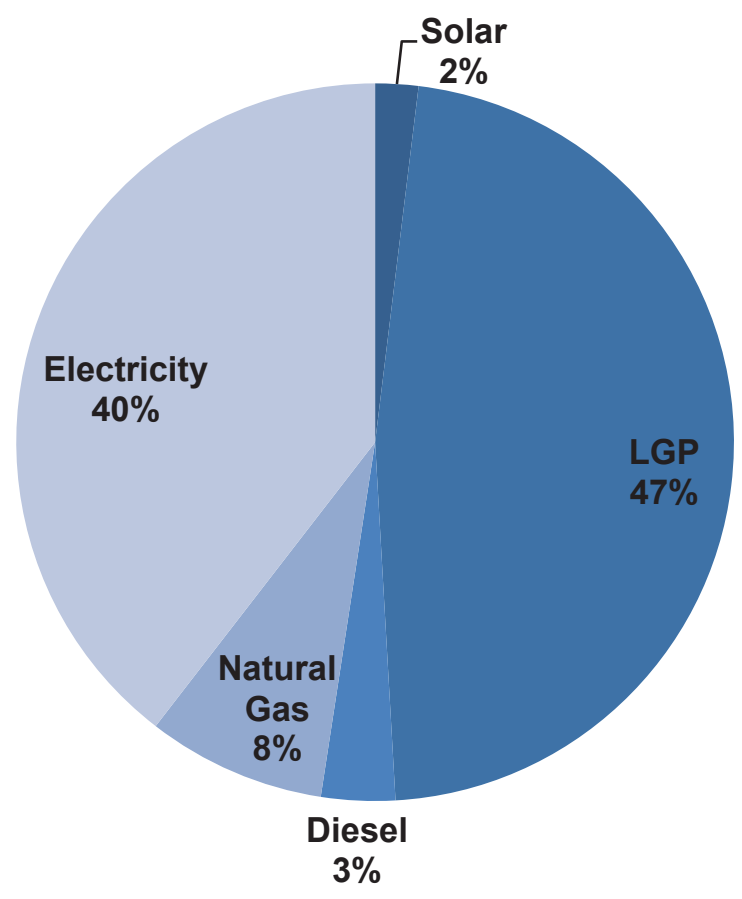

Fig. 2. Share of fuel supply of the Mexican non-domestic sector

\subsection{An overview of the Mexican non-domestic sector energy use}

Recent studies show that the National Energy Balance highly underestimates the non-domestic sector energy use as it does not reflect an accurate energy utilisation of the sector. The main problem is in the inappropriate tariff allocations determined by the public electric company, where all buildings above100 kW of power installed are considered as industrial buildings (de Buen, 2009). Also, data on floor area, number of buildings, and energy use by building or by end use is very limited and dispersed. The only detailed information on energy use (only electricity) by building type that does exist originates from energy audits undertaken by the Mexican Electric Energy Saving Trust (Fideicomiso para el Ahorro de Energía Eléctrica) (FIDE, 2011). These audits are related to energy 
efficiency projects undertaken by the organization in the past 20 years. Based on these audits, seven different types of non-domestic buildings and seven types of end uses can be identified (Table 1).

[Table 1 about here]

Table 1 Characterization of the Mexican non-domestic buildings

\begin{tabular}{l|l} 
Types of buildings & \multicolumn{1}{l}{ Types of end-uses } \\
\hline Hotels & HVAC \\
Offices & Lighting \\
Schools & Refrigeration \\
Hospitals & Lifts and Pumps \\
Restaurants & Internal Equipment \\
Shopping Centres & Cooking \\
Supermarkets & Water Heating
\end{tabular}

The use of the abovementioned classification in this study will allow the presentation of more complex outcomes than those presented in previous investigations of this nature in Mexico.

\section{Methodology and data sources}

Despite the limited availability of data on energy use by building type of in the country, a limited but highly detailed database of end-use information for each type of building was compiled. This information was derived from the audits carried out by FIDE in the last decade and is the only information available in the country. It is important to note that while these cases might not be considered statistically representative of the sector, this limitation was overcome by performing a detailed building physics simulation. The aim of which was to estimate a baseline on electric and gas demand of each type of non-domestic building located in the three different climates of the country. Sector modelling requires a great deal of information on the built form, construction materials, installed building services and the activities carried out in buildings and premises, as well as an indepth understanding of the dynamics of non-domestic building energy use (Bruhns, 2007). The following section presents the development of the modelling framework and discusses its limitations.

\subsection{Development of the Mexican non-domestic energy/exergy (MEN-DEEX) model}

\subsubsection{Archetype development and assumptions}


In developing the MEN-DEEX model, an archetypal simulation model approach was utilised. This approach generalises the characteristics of a particular building type, and represents variability in the building stock by parameterising construction elements, components, design features, and occupancy/usage patterns (Korolija et al., 2013). It is important to note that the main objective of this exercise was not to simulate each building in the sector, but to create archetypes that capture the most common characteristics of each subsector with the intention of obtaining average energy consumption patterns. The basis of the bottom-up archetype approach is to calculate the energy consumption of a set of archetype buildings using the engineering method, i.e. based on technical factors like the floor area, glazing area, U-value of walls, etc., and then using statistical methods (e.g. extrapolation) to give the consumption for the sector as a whole (Dineen and Gallachoir, 2011). Also, there are particularly helpful in stock aggregation, and can be used to make future energy projections at a sectoral level (Famuyibo et al., 2012). The method used to determine the consumption patterns of the different types of buildings is similar to that described in Huang and Broderick (2000) and Griffith and Crawley (2006), however minor changes were introduced in order to adapt MEN-DEEX model to the limitations of current data available for the Mexican stock.

\section{a) Data Sources}

To develop the archetypes, key variables that impact energy use were identified from relevant literature (Famuyibo et al., 2012). These were then combined with data on installed power by facility and installed power by end-use surveyed from the 120 FIDE case studies representing almost 1.75 million $\mathrm{m}^{2}$ of constructed surface. Also, additional data on number of floors, schedules, number of people, activities and technical information about internal equipment was extracted from these cases. For missing data, information from current national and international energy standards for energy efficiency in buildings such as standards related to the envelope, HVAC systems, motors, and lighting were taken into consideration. The sources from each main parameter can be seen in Table 2 .

[Table 2 about here]

Table 2 Models parameters and sources

\begin{tabular}{ll} 
Parameters & Sources \\
\hline Climate & Sistema Meteorológico Nacional (SMN) and TMY2 files \\
Envelope & ASHRAE 1977 Handbook and SENER NOM-008-ENER-2001
\end{tabular}




$\begin{array}{ll}\text { Lighting } & \text { FIDE and SENER NOM-007-ENER 2004 } \\ \text { Motors } & \text { FIDE and SENER NOM-014-ENER-2005 } \\ \text { Gas Boilers } & \text { SENER NOM-003-ENER-2011 } \\ \text { HVAC } & \text { SENER NOM-011-ENER-2006 } \\ \text { Floor area/No. floors } & \text { FIDE case studies } \\ \text { Glazing } & \text { FIDE case studies and SENER NOM-008-ENER-2001 } \\ \text { Schedules } & \text { ASHRAE 90.1-2010 and FIDE case studies } \\ \text { Internal equipment } & \text { FIDE case studies } \\ \text { Refrigeration } & \text { SENER NOM-022/SCFI-2008 }\end{array}$

b) Building size, form, and fenestration

The 120 buildings from the FIDE Cases were virtually surveyed using a Google Maps Area Calculator Tool (Daft Logic, 2014) with the aim of calculating the average building footprint. Furthermore, Google Street View (Google, 2014) was used to approximately determine characteristics such as floor to floor height and fenestration percentage. In the case of building geometry, to simplify the modelling exercise the models are represented by rectangular forms.

\section{c) Envelope characteristics}

In developing the archetypes, it was assumed that a proportion of the current building stock was constructed in the last two decades of the last century. Consequently, the fabric values were taken from a previous ASHRAE Guide (ASHRAE, 1977) and cross-checked with information from the national building regulation NOM-008-ENER-2011. As a result, it is assumed that all models façades characteristics have the same levels of U-values, infiltration, type of glazing (single) and G-values.

\section{d) Schedules, Occupancy and Internal Gains}

Schedules, occupancy patterns, and internal gains from people have a large effect on the modelling outputs. For this study to the key reference document in this regard was the ASHRAE 90.1-2010 (ASHRAE, 2010). This includes standardized occupancy diversity factors for different building types. Furthermore, additional information was derived from the U.S. Department of Energy (DOE) commercial reference buildings (Deru et al., 2011). As an example of the diversity of the models, typical weekday occupancy from the studied buildings is illustrated in Fig.3. 
Fig. 3. Weekday typical occupancy patterns in non-domestic buildings

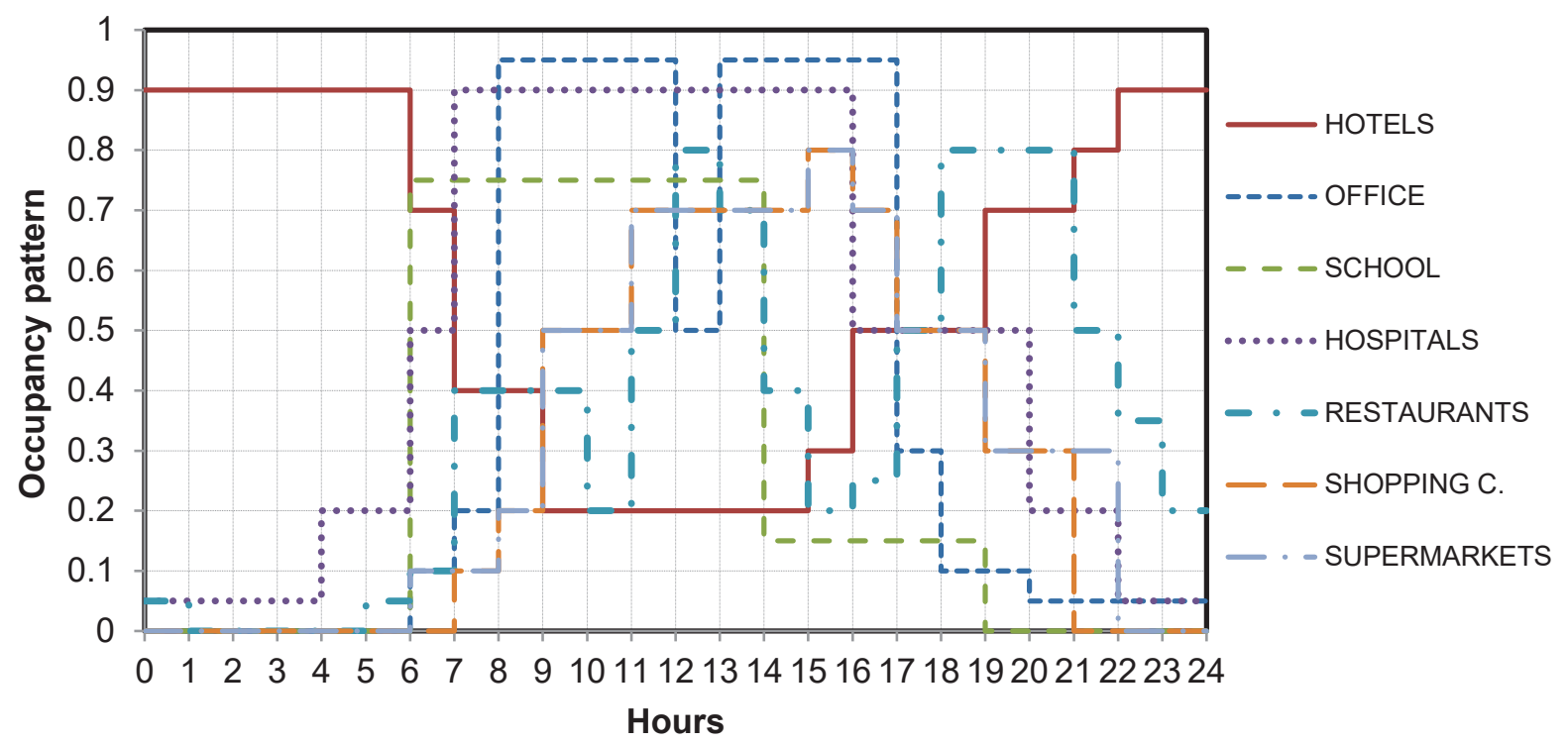

e) General Equipment

Information on internal equipment, lighting power, and HVAC equipment was taken directly from the FIDE case studies. According to the data, with regard to lighting power installed, no significant difference between similar buildings in different regions was found. On the other hand, differences between the installed powers of internal equipment were found. For example, in hospitals, more power installed for equipment can be found in the temperate region than in the hot regions; this may be due to the regional differences in infrastructure and the fact that the majority of specialized hospitals in the urban areas are mainly located in the temperate region. On the other hand, due to increased tourism activity in the hot-humid region more luxury hotels are located and thus present larger values. These differences found in the database analysis were considered in the development of the archetypes. Also, greater electrical efficiencies in pumps and electrical motors were found in buildings located in the temperate and hot-dry region than those in the hot-humid region.

For HVAC and refrigeration equipment, the FIDE case studies showed no heating equipment installed. Conversely, cooling equipment was found on all premises in the hot regions and in almost $50 \%$ of premises in the temperate region (mainly in offices, hospitals and hotels). For water heating boilers it was assumed $\sim 80 \%$ efficiency according to current regulations. Finally, with regard to 
cooking services at schools, restaurants, hospitals and hotels, as no information on cooking equipment exists, the data was derived from the US DOE reference buildings (Deru et al., 2011)..

Based on the preliminary analysis of the FIDE database and the national and international energy standards and studies, the main features of the seven non-domestic archetypes models are described in Table 3.

[Table 3 about here]

Table 3 Archetype descriptions used in the MEN-DEEX model

\begin{tabular}{|c|c|c|c|c|}
\hline Building type & Hotel & Office & School & Hospital \\
\hline Model & 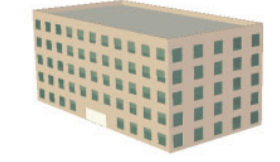 & 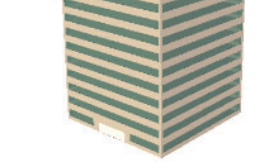 & 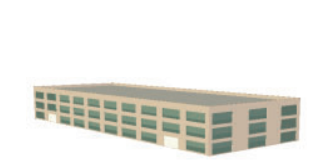 & 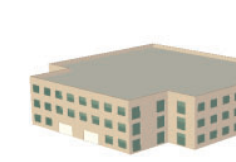 \\
\hline Floor area [m2] & 6,500 & 12,500 & 7,500 & 7,200 \\
\hline No of floors & 5 & 10 & 3 & 3 \\
\hline $\begin{array}{l}\text { Location } \\
\text { Construction }\end{array}$ & $\begin{array}{c}\text { Urban } \\
\text { Masonry- } \\
\text { Concrete Block }\end{array}$ & $\begin{array}{l}\text { Urban } \\
\text { Metal Frame- In } \\
\text { situ concrete }\end{array}$ & $\begin{array}{c}\text { Urban/Rural } \\
\text { Masonry-Concrete } \\
\text { block }\end{array}$ & $\begin{array}{l}\text { Urban } \\
\text { Masonry- }\end{array}$ \\
\hline Cooling equipment & $\begin{array}{l}\text { Chilled water } \\
\text { (elect) }\end{array}$ & $\begin{array}{l}\text { Chilled water } \\
\text { (elect) }\end{array}$ & $\begin{array}{l}\text { Chilled water } \\
\text { (elect) }\end{array}$ & $\begin{array}{l}\text { Chilled water } \\
\text { (elect) }\end{array}$ \\
\hline $\begin{array}{l}\text { External walls U-value } \\
{\left[\mathrm{W} / \mathrm{m}^{2}{ }^{\circ} \mathrm{C}\right]}\end{array}$ & 1.00 & 1.00 & 1.00 & 1.00 \\
\hline $\begin{array}{l}\text { Roof U-value }\left[\mathrm{W} / \mathrm{m}^{2}\right. \\
\left.{ }^{\circ} \mathrm{C}\right]\end{array}$ & 0.64 & 0.64 & 0.64 & 0.64 \\
\hline $\begin{array}{l}\text { Glazing area [\%] } \\
\text { Windows U-value }\end{array}$ & $30 \%$ & $50 \%$ & $30 \%$ & $30 \%$ \\
\hline$\left[\mathrm{W} / \mathrm{m}^{2}{ }^{\circ} \mathrm{C}\right]$ & 5.7 & 5.7 & 5.7 & 5.7 \\
\hline Lighting load $\left[\mathrm{W} / \mathrm{m}^{2}\right]$ & 18 & 14 & 16 & 17 \\
\hline Equipment $\left[\mathrm{W} / \mathrm{m}^{2}\right]$ & $5.0-10$ & $5.0-10$ & $3.0-10$ & $20-40$ \\
\hline $\begin{array}{l}\text { HVAC equipment COP } \\
\text { Refrigeration } \\
\text { compressor COP } \\
\text { Water heating } \\
\text { efficiency }[\%]\end{array}$ & 2.5 & $\mathrm{n} / \mathrm{a}$ & 2.5 & 2.5 \\
\hline
\end{tabular}

Building type Restaurant Shopping Centre

Supermarket

Model

Floor area [m2]

No of floors
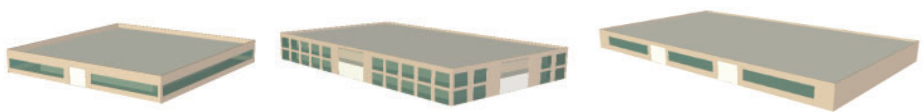

Location

1,500
1
Urban

12,000

9,700

2

1

Urban

Urban 


\begin{tabular}{|c|c|c|c|}
\hline Construction & $\begin{array}{c}\text { Masonry- } \\
\text { Concrete block }\end{array}$ & $\begin{array}{l}\text { Metal Frame- In } \\
\text { situ concrete }\end{array}$ & $\begin{array}{l}\text { Metal Frame- In } \\
\text { situ concrete }\end{array}$ \\
\hline Cooling equipment & $\begin{array}{l}\text { Chilled water } \\
\text { (elect) }\end{array}$ & $\begin{array}{l}\text { Chilled water } \\
\text { (elect) }\end{array}$ & $\begin{array}{l}\text { Chilled water } \\
\text { (elect) }\end{array}$ \\
\hline $\begin{array}{l}\text { External walls U-value } \\
{\left[\mathrm{W} / \mathrm{m}^{2}{ }^{\circ} \mathrm{C}\right]}\end{array}$ & 1.00 & 1.00 & 1.00 \\
\hline $\begin{array}{l}\text { Roof U-value }\left[\mathrm{W} / \mathrm{m}^{2}\right. \\
\left.{ }^{\circ} \mathrm{C}\right]\end{array}$ & 0.64 & 0.64 & 0.64 \\
\hline $\begin{array}{l}\text { Glazing area [\%] } \\
\text { Windows U-value }\end{array}$ & $30 \%$ & $50 \%$ & $10 \%$ \\
\hline$\left[\mathrm{W} / \mathrm{m}^{2}{ }^{\circ} \mathrm{C}\right]$ & 5.7 & 5.7 & 5.7 \\
\hline Lighting load [W/m²] & 16 & 20 & 20 \\
\hline Equipment $\left[\mathrm{W} / \mathrm{m}^{2}\right]$ & 5 & 8 & 8 \\
\hline $\begin{array}{l}\text { HVAC equipment COP } \\
\text { Refrigeration }\end{array}$ & 2.7 & 2.7 & 2.7 \\
\hline $\begin{array}{l}\text { compressor COP } \\
\text { Water heating }\end{array}$ & 2.5 & $\mathrm{n} / \mathrm{a}$ & 2.5 \\
\hline efficiency [\%] & $78-82 \%$ & $78-82 \%$ & $78-82 \%$ \\
\hline
\end{tabular}

To simulate the energy use of the archetypes developed, EnergyPlus (EnergyPlus, 2012) was selected as the calculation tool for first law (energy) analysis. This software is a dynamic simulation tool based on a number of modules that work together to calculate the energy requirements of a building with the potential to model a variety of systems and energy sources. It implements this by simulating the building and associated energy systems when they are exposed to different environmental and operating conditions. EnergyPlus calculated the cooling loads necessary to maintain thermal control setpoint as well as the total electric and thermal energy use by building type and by end use. To model the HVAC, refrigeration and, water heating equipment the function "Autosize" was applied. As previously stated, the COPs and efficiencies were derived from national regulations.

\subsubsection{Weather data and other regional assumptions}

Relevant weather data was taken from the TMY2 format weather files used in the energy simulation process and validated against the national average from climatic data from CONAGUA-SMN (CONAGUA, Accessed: 26 April 2014). This approach allowed to the undertaking of hourly simulations that considered all the dynamic interactions between the building and the external weather throughout the year. The representative cities chosen for this study were Mexico City (temperate climate), Acapulco (hot-humid climate), and Monterrey (hot-dry climate) (Fig. 4). 
[Fig. 4. about here]

Fig. 4. Daily Average Temperature for Mexico City, Acapulco, and Monterrey (TMY2 weather files)

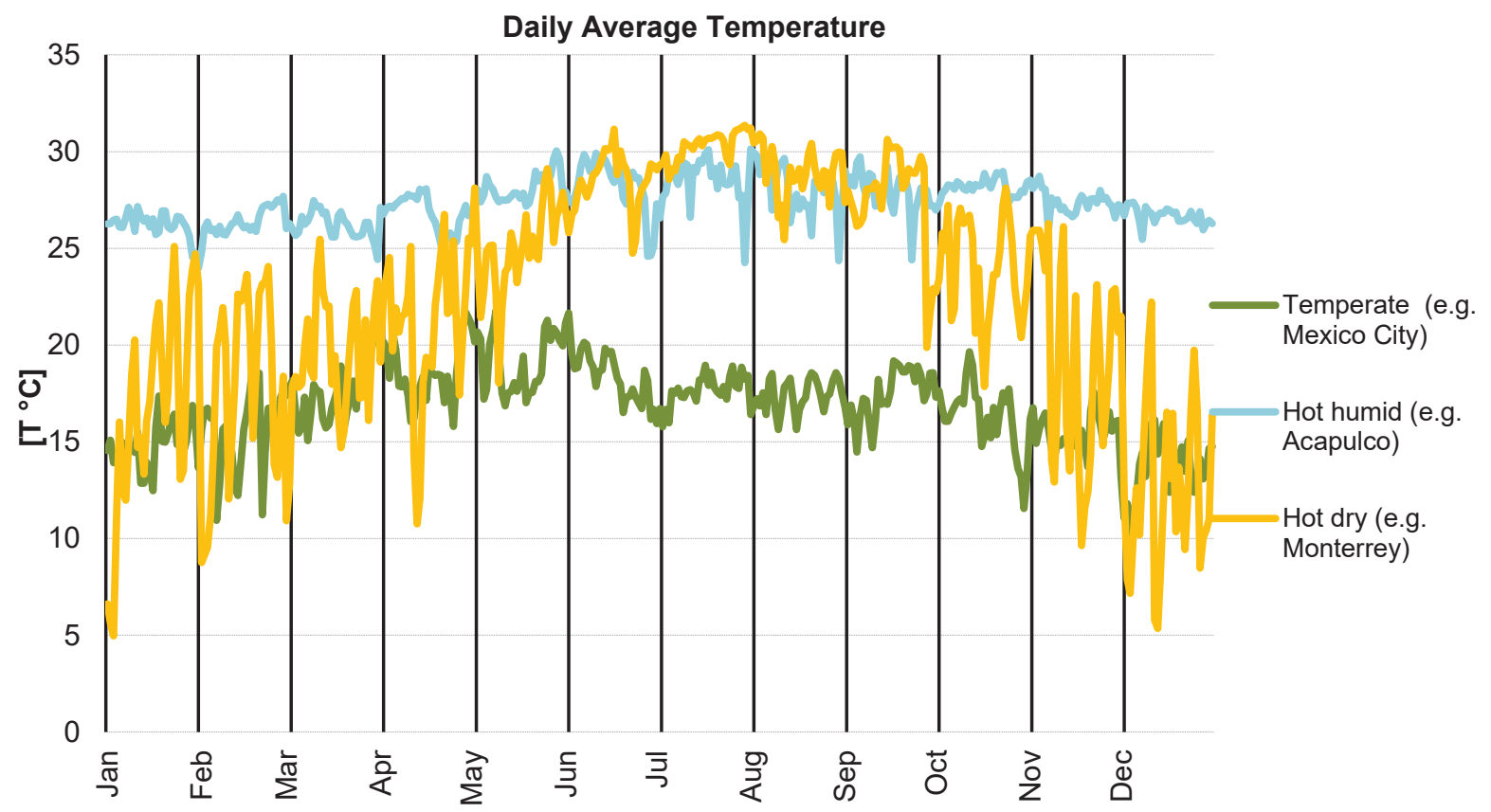

Furthermore, an additional parameter that was considered to have an important effect on energy use and energy efficiency of end-uses such as cooking and water heating, was the cities' altitude. At higher altitudes energy use increases while efficiency is usually lower. This is due to the change in the boiling point of water, which leads to lower system temperatures and increased cooking time.

Considering the most representative cities for every selected climatic region, the average altitudes obtained were 1800 m.a.s.l. (meters above sea level) for the temperate region, 550 m.a.s.l. for the hot dry region, and 20 m.a.s.I. for the hot humid region. Bressani and Chon (1996) investigated the effects of altitude on cooking time in the Central-American region. From the results it was found that between sea level and an altitude of $\sim 500$ m.a.s.l., there is an increase of $38 \%$ in the cooking time, and for an altitude of $\sim 1600$ m.a.s.I. an increase of $64 \%$ in the cooking time was found. Currently EnergyPlus does not model the effects of altitude on cooking, thus in implementing this study these factors were applied for the gas consumption at the corresponding climatic regions.

\subsubsection{Analysing EUI results}


Due to the significant degree of uncertainty regarding archetype characteristics, an important step in the development of the models is the comparison of the simulation results against the real data from the FIDE energy audits. This is undertaken to better match the simulation results to the measured energy end-use intensities and fuel/electric ratios by building type, end-uses, and type of climate. In total twenty-one detailed simulations were performed to obtain EUl's by type of building, by end use and by climatic region. As a comprehensive dynamical simulation was performed, hourly results were obtained from the simulation process. The normalized energy uses from the First Law analysis are shown in Table 4 and Fig. 5. These disaggregated results represent the first instance that such outputs have been produced for Mexican non-domestic stock.

\section{[Table 4 about here]}

Table 4 EUI [kWh/m2-year] by type of building, end-use and climatic region

ELECTRICITY

\begin{tabular}{|c|c|c|c|c|c|c|c|c|c|}
\hline \multirow[b]{2}{*}{ Climate } & \multirow[b]{2}{*}{$\begin{array}{l}\text { Type of } \\
\text { buildings }\end{array}$} & \multirow[b]{2}{*}{ HVAC } & \multicolumn{3}{|c|}{ ELECTRICITY } & \multicolumn{4}{|c|}{ GAS } \\
\hline & & & $\begin{array}{l}\text { Lightin } \\
\mathbf{g}\end{array}$ & $\underset{n}{\text { Refrigeratio }}$ & $\begin{array}{l}\text { Lifts and } \\
\text { Pumps }\end{array}$ & Equipment & Cooking & $\begin{array}{l}\text { Water } \\
\text { Heating }\end{array}$ & $\begin{array}{c}\text { EUI } \\
{\left[\mathrm{kWh} / \mathrm{m}^{2} \text {-year }\right]}\end{array}$ \\
\hline \multirow{7}{*}{ Temperate } & hotels & 83.6 & 48.2 & 3.0 & 5.0 & 15.5 & 32.1 & 35.1 & 222.5 \\
\hline & offices & 27.3 & 58.9 & 0.0 & 13.6 & 9.8 & 0.0 & 2.4 & 112.0 \\
\hline & schools & 2.4 & 27.6 & 0.8 & 1.2 & 8.5 & 15.5 & 6.0 & 61.9 \\
\hline & hospitals & 53.8 & 42.2 & 40.2 & 13.5 & 68.8 & 27.6 & 7.6 & 253.8 \\
\hline & restaurants & 41.8 & 83.7 & 64.7 & 0.0 & 20.1 & 218.1 & 47.8 & 476.1 \\
\hline & shopping c. & 24.3 & 53.8 & 0.0 & 15.4 & 22.4 & 0.0 & 1.2 & 117.1 \\
\hline & supermarkets & 18.2 & 64.7 & 213.9 & 0.0 & 38.0 & 21.8 & 1.5 & 358.0 \\
\hline \multirow{7}{*}{ Hot-humid } & hotels & 170.3 & 47.7 & 11.7 & 28.8 & 22.5 & 19.6 & 21.5 & 322.1 \\
\hline & offices & 130.4 & 44.0 & 0.0 & 16.8 & 8.5 & 0.0 & 0.7 & 200.4 \\
\hline & schools & 49.2 & 40.3 & 0.8 & 5.0 & 2.9 & 9.5 & 4.0 & 111.7 \\
\hline & hospitals & 238.7 & 41.0 & 43.5 & 34.9 & 35.3 & 16.8 & 5.2 & 415.5 \\
\hline & restaurants & 164.4 & 77.5 & 76.9 & 0.0 & 17.5 & 133.0 & 33.9 & 503.1 \\
\hline & shopping c. & 135.0 & 57.9 & 0.0 & 18.2 & 18.2 & 0.0 & 1.2 & 230.4 \\
\hline & supermarkets & 45.6 & 64.6 & 294.9 & 0.0 & 38.0 & 13.3 & 1.5 & 457.9 \\
\hline \multirow{7}{*}{ Hot-dry } & hotels & 179.7 & 62.3 & 15.0 & 31.9 & 36.5 & 27.0 & 26.9 & 379.4 \\
\hline & offices & 103.0 & 39.4 & 0.0 & 18.6 & 6.8 & 0.0 & 0.9 & 168.7 \\
\hline & schools & 85.2 & 53.7 & 0.8 & 14.9 & 15.2 & 13.1 & 4.9 & 187.7 \\
\hline & hospitals & 327.2 & 39.0 & 47.2 & 22.9 & 24.0 & 23.2 & 6.2 & 489.7 \\
\hline & restaurants & 161.2 & 77.5 & 71.8 & 0.0 & 16.2 & 183.5 & 39.3 & 549.5 \\
\hline & shopping c. & 97.2 & 59.2 & 0.0 & 6.3 & 19.2 & 0.0 & 1.2 & 183.1 \\
\hline & supermarkets & 36.5 & 64.6 & 264.1 & 0.0 & 38.0 & 18.4 & 1.3 & 422.9 \\
\hline
\end{tabular}




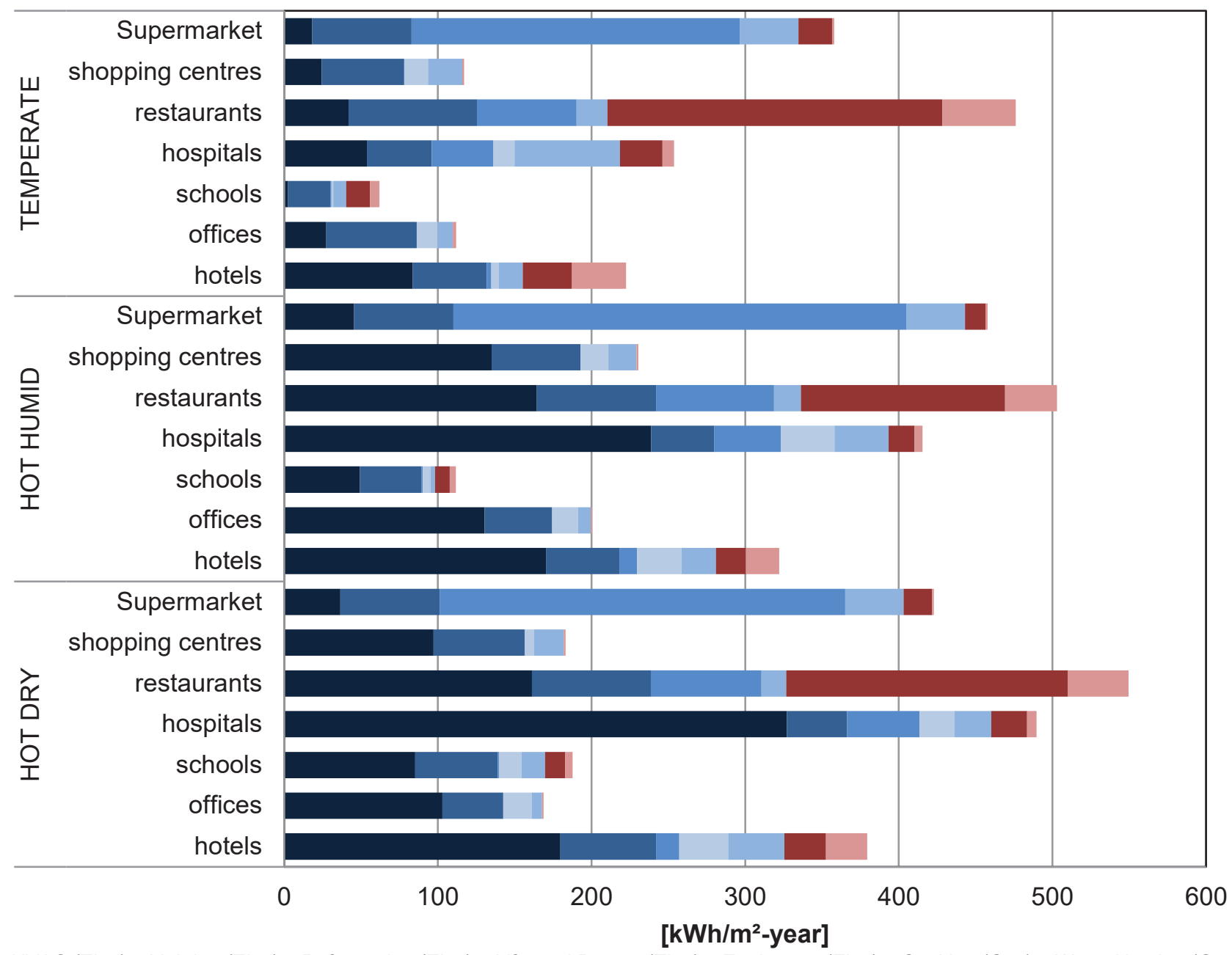

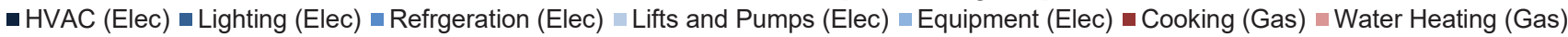

Fig. 5. Energy Use Intensities by buildings and climate zones

\subsubsection{Stock aggregation}

As was previously mentioned, the lack of information on the exact number of premises and/or floor area $\left(\mathrm{m}^{2}\right)$ at a national level is a significant limitation affecting this study. The only study that does include an estimation of the national floor area by type of non-domestic building at a national level was undertaken by the United Nations Environment Programme (UNEP) (de Buen, 2009). Through the use of these values, the regional floor area by building type by using the percentage of urban population at each climatic region was estimated. To obtain these values, data from Instituto Nacional de Estadística y Geografía (INEGI) (INEGI, Accessed: 20 April 2014) was used to estimate the urban 
population by region in an attempt to roughly estimate total regional floor area $\left(\mathrm{m}^{2}\right)$. According to latest INEG/ population census in 2010 , the temperate, the hot-dry region and the hot-humid region encompass $56.14 \%, 24.19 \%$ and $19.67 \%$ respectively of the national urban population. Using these values combined with the data on national floor area an estimation of non-domestic floor area by building and by climatic region was approximated (Table 5). The largest cities representing the temperate region are Mexico City, Guadalajara and Puebla; for the hot-dry climate, Monterrey, Tijuana and Ciudad Juarez; and for the Hot-humid is mainly represented by Merida, Cuernavaca, Acapulco and Cancun.

[Table 5 about here]

Table 5 Estimation of floor area by type of building at every climatic region

\begin{tabular}{lrrrr}
$\begin{array}{l}\text { Types of } \\
\text { buildings }\end{array}$ & \multicolumn{1}{c}{$\begin{array}{c}\text { Hot-dry } \\
\mathbf{m}^{\mathbf{2}}\end{array}$} & $\begin{array}{c}\text { Hot-humid } \\
\mathbf{m}^{\mathbf{2}}\end{array}$ & $\begin{array}{c}\text { Temperate } \\
\mathbf{m}^{\mathbf{2}}\end{array}$ & \multicolumn{1}{c}{$\begin{array}{c}\text { total } \\
\mathbf{m}^{\mathbf{2}}\end{array}$} \\
\hline hotels & $2,903,293$ & $2,360,362$ & $6,736,345$ & $12,000,000$ \\
offices & $1,112,929$ & 904,805 & $2,582,266$ & $4,600,000$ \\
schools & $29,274,875$ & $23,800,313$ & $67,924,812$ & $121,000,000$ \\
hospitals & $1,451,647$ & $1,180,181$ & $3,368,172$ & $6,000,000$ \\
restaurants & 483,882 & 393,394 & $1,122,724$ & $2,000,000$ \\
shopping centres & $2,612,964$ & $2,124,325$ & $6,062,710$ & $10,800,000$ \\
supermarkets & $3,314,593$ & $2,694,746$ & $7,690,660$ & $13,700,000$
\end{tabular}

The results of energy consumption by region as well as the national consumption were assessed by using the EUI by end use obtained from the model multiplied by the estimated floor area based on the following eq. 1:

Regional energy input $P J=\sum_{n}\left(E U I_{n}{ }^{*} \text { regional floor area building }(n)^{*}\left(3.6 \times 10^{-9}\right)\right)^{1}$

\subsection{Sectoral exergy analysis}

The method used to quantify exergy efficiencies for end uses and temperature product assumptions was adapted from Utlu and Hepbasli (2003) and Dincer et al. (2004) and is summarised in this

\footnotetext{
${ }^{1}\left(3.6 \times 10^{-9}\right)$ represents the conversion value from $\mathrm{kWh}$ to $\mathrm{PJ}$
} 
section. Following this, the consumption by region, by building and by end-use was quantified and finally the exergy efficiency of the non-domestic sector was determined. A simplistic energy balance based on the first law can be expressed as:

Energy input - Energy output $=$ Energy accumulation

Conversely, exergy is the part of energy that has the potential to be fully converted into mechanical work due to interactions with the environment, and this will occur until the system and the environment reach a "dead-state". If a reversible process takes place then exergy is conserved, but exergy is always degraded in an irreversible process. This concept can be expressed as:

Exergy input - Exergy output - Exergy consumption $=$ Exergy accumulation

\subsubsection{Reference temperature:}

The most important concept that should be considered when performing an exergy analysis of a given system is the establishment of a reference environment. This is because exergy is not only a property of the system but of both the system and the environment. Gallo and Milanez (1990) presented the concepts of thermomechanical exergy, chemical exergy, and restricted and unrestricted dead state with a particular focus on the reference environment. The authors noted that since the environmental pressure and temperature may vary and the components environment are not in chemical equilibrium, characterization of the reference state presents large difficulties and can therefore be complex to define. To compare different processes, e.g. in the case of different building systems, this can be done by the exergy efficient concept, but the choice of an appropriate reference state is still the major concern. The biggest limitation is that the reference state is always changing; therefore it is not possible to define a theoretically correct reference environment. The reference environment used for the MEN-DEEX model is taken from the same TMY2 file used in the energy analysis, however to simplify the results the mean monthly daily outdoor temperature of each of the regions analysed is considered (Table 6). This approach can determine the differences on monthly exergy destruction in each region with a specific focus on the regions with high temperature fluctuations throughout the year (e.g. hot -dry region).

[Table 6 about here]

Table 6 Monthly average temperatures $\left[{ }^{\circ} \mathrm{C}\right]$ for every climatic region 


\begin{tabular}{cccc} 
Month & Temperate & Hot humid & Hot dry \\
\hline January & 14.9 & 26.2 & 16.8 \\
February & 15.6 & 26.4 & 17.9 \\
March & 17.6 & 26.2 & 19.2 \\
April & 18.6 & 26.9 & 20.9 \\
May & 19.1 & 28.1 & 25.1 \\
June & 18.6 & 28.3 & 28.4 \\
July & 17.6 & 28.4 & 30.2 \\
August & 17.4 & 28.1 & 29.0 \\
September & 17.5 & 28.0 & 27.7 \\
October & 16.3 & 28.1 & 23.9 \\
November & 15.6 & 27.4 & 19.5 \\
December & 13.6 & 26.7 & 12.9
\end{tabular}

For the exergy analysis, apart from the aforementioned reference temperatures $\left(T_{0}\right)$ it was also necessary to identify the product temperature $\left(T_{p}\right)$ of all the processes (as presented in the next section), and the quality of the main energy sources (qfue/). The exergy values or quality from the energy sources analysed were assumed to be 0.92 for gas (natural gas and LPG) and 1.0 for electricity.

\subsubsection{Energy and exergy efficiencies}

The energy and exergy efficiencies for the main end uses identified in the Mexican non-domestic sector are based in the following definitions:

$\eta=$ energy in products / total energy input

$\psi=$ exergy in products / total exergy input

If the energy quality factor of fuels are assumed to be 1.0 (like in the case of electricity), exergy efficiencies can be defined as a function of energy efficiency (Dincer et al., 2004). The following section presents the exergy efficiency formulas used for electrical-based and gas-based end-uses.

\subsubsection{Efficiencies for electric-based end uses}

\section{Space conditioning (Cooling)}

Based on the audits performed by FIDE and the results from the energy modelling it is assumed that the energy use for heating is 0 ; hence cooling represents the total demand for space conditioning. 
The first law modelling results showed that the energy use at a regional level from space conditioning represents $42.1 \%, 40.6 \%$ and $12.1 \%$ for the hot-dry, hot-humid and temperate climate respectively of the regional energy demand. Nationally, cooling in the non-domestic sector represents $29.5 \%$ of the total energy input. Although theoretically the energy efficiency is described in equation 6 , the energy efficiency values were obtained from relevant EnergyPlus outputs.

$\eta_{\text {cooling }}=\frac{Q_{p}}{W_{e}}$

The second law efficiency was calculated using the following equation:

$\psi_{\text {cooling }}\left(t_{k}\right)=\left(1-\frac{T_{0}\left(t_{k}\right)}{T_{p_{\text {cooling }}\left(t_{k}\right)}}\right) * \eta_{\text {cooling }}\left(t_{k}\right)=\left(1-\frac{T_{0}\left(t_{k}\right)}{T_{p_{-} \text {cooling }}\left(t_{k}\right)}\right) * \operatorname{COP}\left(t_{k}\right)$

The reference temperatures $\left(T_{0}\right)$ represent the regional monthly average (Table 6). $T_{p_{-} \text {cooling }}$ Was considered to be $23^{\circ} \mathrm{C}(296.15 \mathrm{~K})$ for all regions. The average COP or $\eta_{\text {cooling }}$ obtained from the simulation outputs and the results for monthly exergy efficiency are listed in Table 7.

[Table 7 about here]

Table 7 Monthly average COP and exergy efficiency of cooling processes for every climatic region

Temperate

Hot-humid

Hot-dry

\begin{tabular}{ccccccc} 
Month & $\begin{array}{c}\text { Average } \\
\text { COP }\end{array}$ & $\boldsymbol{\Psi}$ & $\begin{array}{c}\text { Average } \\
\text { COP }\end{array}$ & $\boldsymbol{\psi}$ & $\begin{array}{c}\text { Average } \\
\text { COP }\end{array}$ & $\boldsymbol{\Psi}$ \\
\hline January & 3.4 & $\underline{9.3 \%}$ & 3.2 & $3.4 \%$ & 2.5 & $\underline{5.2 \%}$ \\
February & 3.3 & $\underline{8.4 \%}$ & 3.2 & $3.7 \%$ & 2.5 & $\underline{4.2 \%}$ \\
March & 3.3 & $\underline{6.0 \%}$ & 3.2 & $3.4 \%$ & 2.4 & $\underline{3.1 \%}$ \\
April & 3.2 & $\underline{4.8 \%}$ & 3.2 & $4.1 \%$ & 2.4 & $\underline{1.7 \%}$ \\
May & 3.2 & $\underline{4.2 \%}$ & 3.2 & $5.4 \%$ & 2.3 & $1.6 \%$ \\
June & 3.2 & $\underline{4.8 \%}$ & 3.1 & $5.6 \%$ & 2.2 & $4.1 \%$ \\
July & 3.3 & $\underline{5.9 \%}$ & 3.1 & $5.8 \%$ & 2.2 & $5.3 \%$ \\
August & 3.3 & $\underline{6.2 \%}$ & 3.2 & $5.5 \%$ & 2.2 & $4.6 \%$ \\
September & 3.3 & $\underline{6.1 \%}$ & 3.2 & $5.3 \%$ & 2.3 & $3.6 \%$ \\
October & 3.3 & $\underline{7.5 \%}$ & 3.2 & $5.5 \%$ & 2.3 & $0.7 \%$ \\
November & 3.3 & $\underline{8.4 \%}$ & 3.2 & $4.8 \%$ & 2.5 & $2.9 \%$
\end{tabular}




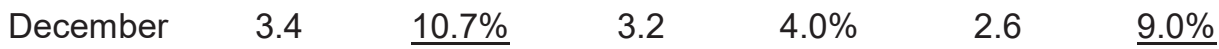

Theoretically in months where the setpoint temperature is above the external temperature (e.g. all year for the temperate region, and 6 months for the hot dry region) the buildings will not require cooling. However, since a dynamic energy analysis was performed, hourly temperature fluctuations are considered in particular instances where the external temperature exceeds the reference setpoint. Additionally, the model considers the heat gains from occupant activity, lighting and electrical equipment. Therefore, the results of the energy analysis illustrated that cooling demand is present even though the external temperature is lower than the setpoint due to the internal gains listed. In this case, loads will mainly be met by ventilation, infiltration, transmission and to a lesser extent by the artificial cooling; on the other hand, when it is warmer outside than it is inside, the demand is mainly met by the artificial cooling process. Hence, internal gains are the main reason why cooling is needed almost every day of the year in the temperate region and in the winter season in the hot-dry region. To illustrate this, a comparison of monthly cooling demands between regions for a typical office building is shown in Figure 6.

[Fig. 6. about here]

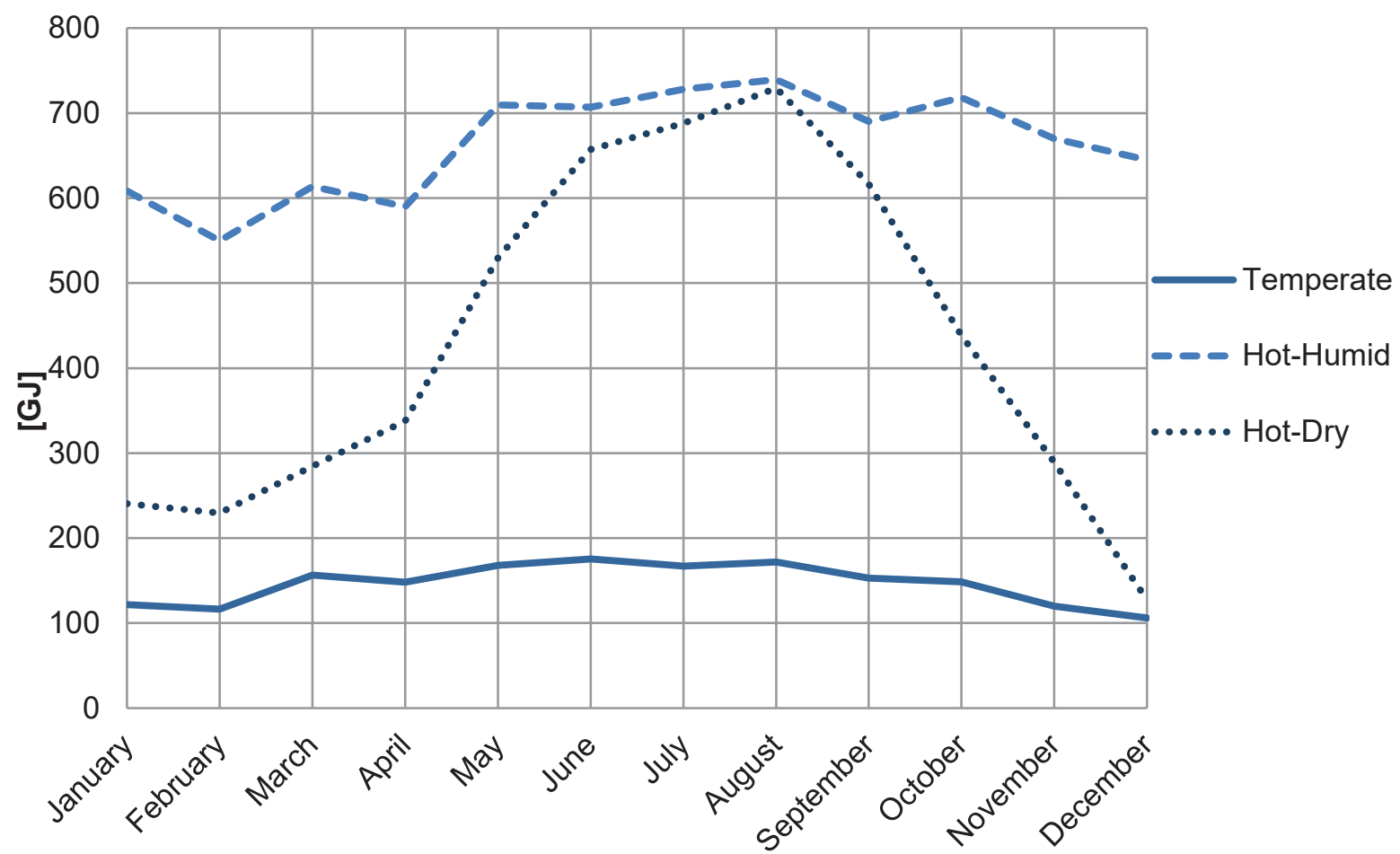

Fig. 6 Regional monthly cooling demand for typical office building in Mexico 
In energy analysis, when a cooling demand is presented a required energy output from the system is required. But In exergy terms a cooling load can represent a demanded exergy input or exergy output, depending on the reference temperature. When the outside temperature is higher (e.g. hot humid), input exergy is required to remove the heat. On the other hand, when outside is cooler and still a cooling demand exist, the building has an unwanted warm exergy inside the building and thus it has to be removed (ECB-Annex 49, 2009). The latest are represented in Table 7 by the underlined exergy efficiency results.

\section{$\underline{\text { Refrigeration }}$}

Refrigeration is not as representative as space conditioning but also has a large impact on total energy use. Of the total energy use by region, this end use represents $10.8 \%, 15.3 \%$ and $17.7 \%$ for the hot-dry, hot-humid and temperate climate respectively. Nationally, represents $14.7 \%$ of the total energy input for the sector. The second law efficiency was calculated using equation 8.

$\psi_{\text {ref }}\left(t_{k}\right)=\eta_{\text {ref }}\left(t_{k}\right) *\left(\frac{T_{0}\left(t_{k}\right)}{T_{p_{-} r e f r}\left(t_{k}\right)}-1\right)=\operatorname{COP}_{\text {ref }}\left(t_{k}\right) *\left(\frac{T_{0}\left(t_{k}\right)}{T_{p_{-} r e f r}\left(t_{k}\right)}-1\right)$

Both $\mathrm{COP}_{r e f}$ (or $\eta_{r e f}$ ) and the mean monthly reference temperatures $\left(T_{0}\right)$ represented by the internal environment of buildings are taken from the simulation outputs. Meanwhile $T_{p_{-} r e f r}$ was considered to be $-8{ }^{\circ} \mathrm{C}(265.15 \mathrm{~K})$ for all regions. The considered reference temperatures and monthly exergy efficiency results for refrigeration can be seen in Table 8 .

\section{[Table 8 about here]}

Table 8 Average internal temperature, monthly average COP and exergy efficiency of refrigeration processes for every climatic region

\begin{tabular}{|c|c|c|c|c|c|c|c|c|c|}
\hline Month & $\begin{array}{c}\text { Avg. } \\
\text { Int. } \\
\text { Temp. } \\
{\left[{ }^{\circ} \mathrm{C}\right]}\end{array}$ & $\begin{array}{c}\text { Average } \\
\text { COP }\end{array}$ & rate & $\begin{array}{c}\text { Avg. } \\
\text { Int. } \\
\text { Temp. } \\
{\left[{ }^{\circ} \mathrm{C}\right]}\end{array}$ & $\begin{array}{c}\text { Average } \\
\text { COP }\end{array}$ & mid & $\begin{array}{c}\text { Avg. } \\
\text { Int. } \\
\text { Temp. } \\
{\left[{ }^{\circ} \mathrm{C}\right]}\end{array}$ & $\begin{array}{c}\text { Average } \\
\text { COP }\end{array}$ & $\psi$ \\
\hline January & 19.5 & 1.9 & $20.1 \%$ & 21.7 & 1.6 & $17.7 \%$ & 20.0 & 1.9 & $19.6 \%$ \\
\hline February & 19.7 & 1.9 & $19.9 \%$ & 21.7 & 1.6 & $17.6 \%$ & 20.0 & 1.8 & $19.4 \%$ \\
\hline March & 20.0 & 1.8 & $19.5 \%$ & 21.7 & 1.6 & $17.7 \%$ & 20.3 & 1.8 & $19.2 \%$ \\
\hline April & 20.1 & 1.8 & $19.2 \%$ & 21.8 & 1.6 & $17.5 \%$ & 20.7 & 1.7 & $18.7 \%$ \\
\hline May & 20.4 & 1.8 & $19.2 \%$ & 22.1 & 1.5 & $17.4 \%$ & 21.7 & 1.6 & $18.0 \%$ \\
\hline
\end{tabular}




$\begin{array}{cccccccccc}\text { June } & 20.9 & 1.8 & 19.7 \% & 22.5 & 1.5 & 17.6 \% & 22.5 & 1.5 & 17.6 \% \\ \text { July } & 21.0 & 1.8 & 20.1 \% & 22.8 & 1.5 & 17.7 \% & 22.8 & 1.5 & 17.4 \% \\ \text { August } & 21.0 & 1.9 & 20.2 \% & 22.7 & 1.5 & 17.7 \% & 22.8 & 1.5 & 17.5 \% \\ \text { September } & 20.6 & 1.8 & 19.9 \% & 22.4 & 1.5 & 17.6 \% & 22.4 & 1.5 & 17.7 \% \\ \text { October } & 19.9 & 1.9 & 19.8 \% & 22.1 & 1.5 & 17.4 \% & 21.5 & 1.6 & 18.3 \% \\ \text { November } & 19.6 & 1.9 & 19.9 \% & 21.9 & 1.6 & 17.5 \% & 20.5 & 1.8 & 19.2 \% \\ \text { December } & 19.3 & 2.0 & 20.2 \% & 21.8 & 1.6 & 17.6 \% & 19.3 & 2.0 & 20.4 \%\end{array}$

\section{Electrical equipment (Lighting, lifts and pumps, and internal equipment)}

Not only does lighting consume a significant amount of energy in the country, it is also extremely energy inefficient $\left(\eta_{\text {light }} \approx 20 \%\right.$ ). Of the total energy use by region, lighting represents $23.4 \%, 24.7 \%$ and $31.4 \%$ for the hot-dry, hot-humid and temperate climate respectively. Nationally represents $27.0 \%$ of the total energy input for the sector. As the electromagnetic radiation has similar energy and exergy contents, the energy and exergy efficiencies of lighting are almost similar (Rosen and Bulucea, 2009). Other electric end-uses such as motors and pumps, and miscellaneous equipment represent $4.4 \%$ and $9.4 \%$ respectively of the national energy use in the non-domestic sector. Also, it is considered that energy and exergy efficiency are similar to the conversion of electricity into high quality work.

The second law efficiency for electric-based equipment is defined as:

$\psi_{\text {elec }} \approx \eta_{\text {elec }}$

For the analysis, lighting is considered to have a constant monthly exergy efficiency of $18.1 \%$. For lift and pumps is considered $50.0 \%$, and for internal equipment $70.0 \%$.

\subsubsection{Efficiencies for gas-based end uses}

\section{Water heating}

The modelling results indicate that regional energy use for water heating from gas consumption represents $2.7 \%, 2.9 \%$ and $6.9 \%$ for the hot-dry, hot-humid and temperate climates respectively. The national energy use is estimated to be $4.4 \%$ of the total energy input. In this study it is assumed that $100 \%$ of water heating is produced by gas boilers with an efficiency $\left(\eta_{W H}\right)$ of $78-82 \%$ according to 
national regulations (SENER, 2011). Due to the higher altitudes, lower efficiencies are assumed for the hot dry and temperate regions. By building type, hotels and restaurants have a larger share of heated water than the other sectors. The second law efficiency was calculated using equation 10.

$\psi_{W H}\left(t_{k}\right)=\frac{\eta_{W H}\left(t_{k}\right)}{q_{\text {fuel }}} *\left(1-\left(\frac{T_{0}\left(t_{k}\right)}{T_{p_{-} W H}\left(t_{k}\right)-T_{0}\left(t_{k}\right)}\right) * \ln \left(\frac{T_{p_{-} W H}\left(t_{k}\right)}{T_{0}\left(t_{k}\right)}\right)\right)$

The reference temperatures $\left(T_{0}\right)$ represent the regional monthly average temperature (Table 6$)$ and $T_{p_{-} W H}$ was considered to be $82^{\circ} \mathrm{C}(355.15 \mathrm{~K})$ for all regions. The results can be seen in Table 9 .

[Table 9 about here]

Table 9 Average energy and exergy efficiency of water heating processes for every climatic region

\begin{tabular}{ccccccc} 
& \multicolumn{2}{c}{ Temperate } & \multicolumn{2}{c}{ Hot-humid } & \multicolumn{2}{c}{ Hot-dry } \\
Month & $\boldsymbol{\eta}$ & $\boldsymbol{\psi}$ & $\boldsymbol{\eta}$ & $\boldsymbol{\psi}$ & $\boldsymbol{\eta}$ & $\boldsymbol{\Psi}$ \\
\hline January & $78 \%$ & $8.6 \%$ & $82 \%$ & $7.4 \%$ & $80 \%$ & $8.5 \%$ \\
February & $78 \%$ & $8.5 \%$ & $82 \%$ & $7.4 \%$ & $80 \%$ & $8.4 \%$ \\
March & $78 \%$ & $8.2 \%$ & $82 \%$ & $7.4 \%$ & $80 \%$ & $8.2 \%$ \\
April & $78 \%$ & $8.1 \%$ & $82 \%$ & $7.3 \%$ & $80 \%$ & $7.9 \%$ \\
May & $78 \%$ & $8.0 \%$ & $82 \%$ & $7.1 \%$ & $80 \%$ & $7.4 \%$ \\
June & $78 \%$ & $8.1 \%$ & $82 \%$ & $7.1 \%$ & $80 \%$ & $6.9 \%$ \\
July & $78 \%$ & $8.2 \%$ & $82 \%$ & $7.1 \%$ & $80 \%$ & $6.7 \%$ \\
August & $78 \%$ & $8.2 \%$ & $82 \%$ & $7.1 \%$ & $80 \%$ & $6.8 \%$ \\
September & $78 \%$ & $8.2 \%$ & $82 \%$ & $7.1 \%$ & $80 \%$ & $7.0 \%$ \\
October & $78 \%$ & $8.4 \%$ & $82 \%$ & $7.1 \%$ & $80 \%$ & $7.5 \%$ \\
November & $78 \%$ & $8.5 \%$ & $82 \%$ & $7.2 \%$ & $80 \%$ & $8.2 \%$ \\
December & $78 \%$ & $8.7 \%$ & $82 \%$ & $7.3 \%$ & $80 \%$ & $9.1 \%$
\end{tabular}

\section{Cooking}

It is estimated that all the cooking activities directly use fossil fuels and thus electric cooking is estimated to be 0 . From the model outputs, cooking represents $6.7 \%, 6.3 \%$ and $16.4 \%$ for the hot-dry, hot-humid and temperate climates respectively. The national energy use is estimated to be $10.6 \%$ of 
the total energy input. At higher altitudes since the air pressure is lower and the boiling point of water is lower, cooking times need to be increased. Hence, First Law efficiency for natural gas and LGP cooking was assumed to be $50 \%$ at sea level (Utlu and Hepbasli, 2003), $45 \%$ at 800 m.a.s.l. and $40 \%$ at 1500 m.a.s.l. The second law efficiency was calculated using equation 11.

$\psi_{\text {cooking }}=\eta_{\text {cooking }}\left(t_{k}\right) *\left(1-\frac{T_{0}\left(t_{k}\right)}{T_{p_{\text {cook }}\left(t_{k}\right)}}\right)$

The reference temperatures $\left(T_{0}\right)$ represent the regional monthly average temperature (Table 6). As water boils at a lower temperature at higher altitudes $T_{p_{-} \text {cook }}$ was considered to be $140{ }^{\circ} \mathrm{C}(403.15 \mathrm{~K})$ for the humid region, $135^{\circ} \mathrm{C}(398.15 \mathrm{~K})$ for the dry region and $130{ }^{\circ} \mathrm{C}(393.15 \mathrm{~K})$ for the temperate region. Cooking at lower temperatures increases cooking time. These factors were already considered in the energy analysis model as mentioned in section 3.1.2. The exergy efficiency results are shown in Table 10.

[Table 10 about here]

Table 10 Average energy and exergy efficiency of cooking processes for every climatic region

\begin{tabular}{ccccccc} 
& \multicolumn{2}{c}{ Temperate } & \multicolumn{2}{c}{ Hot-humid } & \multicolumn{2}{c}{ Hot-dry } \\
Month & $\boldsymbol{\eta}$ & $\boldsymbol{\Psi}$ & $\boldsymbol{\eta}$ & $\boldsymbol{\Psi}$ & $\boldsymbol{\eta}$ & $\boldsymbol{\psi}$ \\
\hline January & $40 \%$ & $11.4 \%$ & $50 \%$ & $13.8 \%$ & $45 \%$ & $13.0 \%$ \\
February & $40 \%$ & $11.4 \%$ & $50 \%$ & $13.7 \%$ & $45 \%$ & $12.9 \%$ \\
March & $40 \%$ & $11.2 \%$ & $50 \%$ & $13.8 \%$ & $45 \%$ & $12.8 \%$ \\
April & $40 \%$ & $11.1 \%$ & $50 \%$ & $13.7 \%$ & $45 \%$ & $12.6 \%$ \\
May & $40 \%$ & $11.0 \%$ & $50 \%$ & $13.5 \%$ & $45 \%$ & $12.1 \%$ \\
June & $40 \%$ & $11.1 \%$ & $50 \%$ & $13.5 \%$ & $45 \%$ & $11.8 \%$ \\
July & $40 \%$ & $11.2 \%$ & $50 \%$ & $13.5 \%$ & $45 \%$ & $11.6 \%$ \\
August & $40 \%$ & $11.2 \%$ & $50 \%$ & $13.5 \%$ & $45 \%$ & $11.7 \%$ \\
September & $40 \%$ & $11.2 \%$ & $50 \%$ & $13.6 \%$ & $45 \%$ & $11.8 \%$ \\
October & $40 \%$ & $11.3 \%$ & $50 \%$ & $13.5 \%$ & $45 \%$ & $12.3 \%$ \\
November & $40 \%$ & $11.4 \%$ & $50 \%$ & $13.6 \%$ & $45 \%$ & $12.7 \%$ \\
December & $40 \%$ & $11.6 \%$ & $50 \%$ & $13.7 \%$ & $45 \%$ & $13.5 \%$
\end{tabular}


The classification presented in this paper allows for a deeper understanding of the energy and exergy utilisation of the sector. Efficiencies at the building, regional and national level can be calculated using the obtained exergy efficiencies and multiplying them by the calculated exergy input by enduse. Later, to obtain the regional energy and exergy efficiency we aggregate the energy data obtained from the energy analysis; for this purpose we use equations 12 and 13. Finally, a national energy/exergy efficiency of the sector is obtained using the similar equations to known the efficiency of the sector as a whole and to make direct comparison with other international studies.

$\eta_{t o t}=\frac{\sum f_{i} * \eta_{i}}{\sum f_{i}}$

$\psi_{\text {tot }}=\frac{\sum f_{i^{*}} \psi_{i}}{\sum f_{i}}$

$f_{i}$ refers to the fraction of the total energy/exergy utilisation of a specific end-use, $\eta_{i}$ to the energy efficiency, and $\psi_{i}$ to the exergy efficiency of each end-use.

\section{Results and Discussion.}

\subsection{Energy utilisation in the non-domestic sector}

The model output showed a total energy input of $95.43 \mathrm{PJ} ; 81.10 \mathrm{PJ}$ in form of electricity and 14.32 PJ in for of gas (LNG and Natural Gas). Although schools are the type of building with the lowest EUI of all analysed buildings, nationwide the constructed surface of schools represents $71 \%$ of the total non-domestic sector floor area, thus schools comprise $46.6 \%$ of the total yearly energy input (44.49 PJ) in the sector. Schools in the hot-dry climate are the major consumers with an utilisation of 19.78 PJ of energy. Of that amount, 8.97 PJ are used to cover the energy demand for space conditioning. This individual end-use represents $9.4 \%$ of the total sectoral energy input. Also, schools in the hothumid and temperate climates are large consumers with a total utilisation of 9.57 PJ and 15.14 PJ respectively. Other large nationwide energy users are supermarkets and hotels representing $20.3 \%$ and $12.7 \%$ respectively.

By end use at a national level, HVAC and Lighting are the dominant end-users, representing $29.5 \%$ and $27.0 \%$ of the total energy input. From a first law perspective special attention has to be put on these end-uses to minimize the energy demand. The overall energy efficiency of the sector was found 
to be $66.4 \%$. The total values for total annual energy input per region, type of building, and type of end-use obtained by the model can be seen in Table 11.

[Table11 about here]

Table 11 Total energy input by climatic region, type of building, and end-use. Values in [PJ]

\begin{tabular}{|c|c|c|c|c|c|c|c|c|c|}
\hline \multirow[b]{2}{*}{ Climate } & \multirow[b]{2}{*}{$\begin{array}{c}\text { Type of } \\
\text { buildings }\end{array}$} & \multirow[b]{2}{*}{ HVAC } & \multicolumn{3}{|c|}{ ELECTRICITY [PJ] } & \multicolumn{4}{|c|}{ GAS [PJ] } \\
\hline & & & $\begin{array}{l}\text { Lightin } \\
\mathbf{g}\end{array}$ & $\begin{array}{c}\text { Refrigeratio } \\
\mathrm{n}\end{array}$ & $\begin{array}{l}\text { Lifts } \\
\text { and } \\
\text { Pumps }\end{array}$ & $\begin{array}{l}\text { Internal } \\
\text { Equip. }\end{array}$ & $\begin{array}{l}\text { Cookin } \\
\mathbf{g}\end{array}$ & $\begin{array}{c}\text { Water } \\
\text { Heati } \\
\text { ng }\end{array}$ & $\begin{array}{l}\text { Total } \\
\text { [PJ] }\end{array}$ \\
\hline \multirow{7}{*}{ Hot-dry } & hotels & 1.88 & 0.65 & 0.16 & 0.33 & 0.38 & 0.28 & 0.28 & 3.97 \\
\hline & offices & 0.41 & 0.16 & 0.00 & 0.07 & 0.03 & 0.00 & 0.00 & 0.68 \\
\hline & schools & 8.98 & 5.66 & 0.08 & 1.57 & 1.60 & 1.38 & 0.52 & 19.79 \\
\hline & hospitals & 1.71 & 0.20 & 0.25 & 0.12 & 0.13 & 0.12 & 0.03 & 2.56 \\
\hline & restaurants & 0.28 & 0.14 & 0.13 & 0.00 & 0.03 & 0.32 & 0.07 & 0.96 \\
\hline & $\begin{array}{l}\text { shopping } \\
\text { centres }\end{array}$ & 0.91 & 0.56 & 0.00 & 0.06 & 0.18 & 0.00 & 0.01 & 1.72 \\
\hline & $\begin{array}{l}\text { supermark } \\
\text { ets }\end{array}$ & 0.44 & 0.77 & 3.15 & 0.00 & 0.45 & 0.22 & 0.02 & 5.05 \\
\hline \multirow{7}{*}{ Hot-humid } & hotels & 1.45 & 0.41 & 0.10 & 0.24 & 0.19 & 0.17 & 0.18 & 2.74 \\
\hline & offices & 0.42 & 0.14 & 0.00 & 0.05 & 0.06 & 0.00 & 0.00 & 0.69 \\
\hline & schools & 4.21 & 3.45 & 0.07 & 0.43 & 0.25 & 0.81 & 0.34 & 9.57 \\
\hline & hospitals & 1.01 & 0.17 & 0.18 & 0.15 & 0.15 & 0.07 & 0.02 & 1.77 \\
\hline & restaurants & 0.23 & 0.11 & 0.11 & 0.00 & 0.02 & 0.19 & 0.05 & 0.71 \\
\hline & $\begin{array}{l}\text { shopping } \\
\text { centres }\end{array}$ & 1.03 & 0.44 & 0.00 & 0.14 & 0.14 & 0.00 & 0.01 & 1.76 \\
\hline & $\begin{array}{c}\text { supermark } \\
\text { ets }\end{array}$ & 0.44 & 0.63 & 2.86 & 0.00 & 0.37 & 0.13 & 0.01 & 4.44 \\
\hline \multirow{8}{*}{ Temperate } & hotels & 2.03 & 1.17 & 0.07 & 0.12 & 0.38 & 0.78 & 0.85 & 5.40 \\
\hline & offices & 0.25 & 0.55 & 0.00 & 0.13 & 0.09 & 0.00 & 0.02 & 1.04 \\
\hline & schools & 0.59 & 6.74 & 0.19 & 0.29 & 2.07 & 3.80 & 1.47 & 15.14 \\
\hline & hospitals & 0.65 & 0.51 & 0.49 & 0.16 & 0.83 & 0.33 & 0.09 & 3.08 \\
\hline & restaurants & 0.17 & 0.34 & 0.26 & 0.00 & 0.08 & 0.88 & 0.19 & 1.92 \\
\hline & $\begin{array}{l}\text { shopping } \\
\text { centres }\end{array}$ & 0.53 & 1.17 & 0.00 & 0.34 & 0.49 & 0.00 & 0.03 & 2.56 \\
\hline & $\begin{array}{l}\text { supermark } \\
\text { ets }\end{array}$ & 0.50 & 1.79 & 5.92 & 0.00 & 1.05 & 0.60 & 0.04 & 9.91 \\
\hline & Total [PJ] & 28.14 & 25.76 & 14.01 & 4.21 & 8.98 & 10.08 & 4.24 & 95.43 \\
\hline
\end{tabular}

\subsubsection{Comparative validation}

In the past years, the National Commission for Efficient Energy Use (CONNUE, 2013) (a subdepartment of the Energy Department) attempted to alleviate the lack of national energy statistics for non-domestic buildings by cleaning and analysing data on what is considered to be "Medium Industry" buildings. A recent study reported that the non-residential sector have an actual annual energy input 
of $25,220 \mathrm{GWh}$ (90.79 PJ). The results for energy use from the simulation model were found to be in strong agreement with those published by CONNUE with a prediction error of $4.86 \%$.

\subsection{Exergy utilisation of the Mexican non-domestic sector}

As a result of the high quality of the sources used in the non-domestic sector (electricity $=1$ and gas $=$ $0.92)$ the exergy input values look similar to those listed in table 11. The total exergy input for the Mexican non-domestic sector was calculated to be 94.28 PJ (81.10 PJ for electricity and 13.18 PJ for gas). However the values of interest to this study are the total exergy output with the intention to obtain building, regional, and national exergy destructions and exergy efficiencies. Based on the aforementioned exergy analysis methodology described these values are presented in Table 12 .

[Table 12 about here]

Table 12 Total exergy output by climatic region, type of building, and end-use. Values in [PJ]

\begin{tabular}{|c|c|c|c|c|c|c|c|c|c|}
\hline \multirow[b]{2}{*}{ Climate } & \multirow[b]{2}{*}{$\begin{array}{c}\text { Type of } \\
\text { buildings }\end{array}$} & \multirow[b]{2}{*}{ HVAC } & \multicolumn{3}{|c|}{ ELECTRICITY [PJ] } & \multicolumn{4}{|c|}{ GAS [PJ] } \\
\hline & & & $\begin{array}{l}\text { Lightin } \\
\mathbf{g}\end{array}$ & $\underset{\mathbf{n}}{\text { Refrigeratio }}$ & $\begin{array}{l}\text { Lifts } \\
\text { and } \\
\text { Pumps }\end{array}$ & $\begin{array}{c}\text { Internal } \\
\text { Equip. }\end{array}$ & $\begin{array}{c}\text { Cookin } \\
\mathbf{g}\end{array}$ & $\begin{array}{c}\text { Water } \\
\text { Heati } \\
\text { ng }\end{array}$ & $\begin{array}{l}\text { Total } \\
\text { [PJ] }\end{array}$ \\
\hline \multirow{7}{*}{ Hot-dry } & hotels & 0.07 & 0.12 & 0.03 & 0.17 & 0.27 & 0.03 & 0.02 & 0.71 \\
\hline & offices & 0.01 & 0.03 & 0.00 & 0.04 & 0.02 & 0.00 & 0.00 & 0.10 \\
\hline & schools & 0.33 & 1.07 & 0.01 & 0.78 & 1.12 & 0.16 & 0.04 & 3.51 \\
\hline & hospitals & 0.06 & 0.04 & 0.05 & 0.06 & 0.09 & 0.01 & 0.00 & 0.31 \\
\hline & restaurants & 0.01 & 0.03 & 0.02 & 0.00 & 0.02 & 0.04 & 0.00 & 0.12 \\
\hline & $\begin{array}{l}\text { shopping } \\
\text { centres }\end{array}$ & 0.03 & 0.10 & 0.00 & 0.03 & 0.13 & 0.00 & 0.00 & 0.30 \\
\hline & $\begin{array}{c}\text { supermark } \\
\text { ets }\end{array}$ & 0.02 & 0.15 & 0.58 & 0.00 & 0.32 & 0.02 & 0.00 & 1.09 \\
\hline \multirow{7}{*}{ Hot-humid } & hotels & 0.07 & 0.08 & 0.02 & 0.12 & 0.13 & 0.02 & 0.01 & 0.45 \\
\hline & offices & 0.02 & 0.03 & 0.00 & 0.03 & 0.04 & 0.00 & 0.00 & 0.12 \\
\hline & schools & 0.20 & 0.65 & 0.01 & 0.22 & 0.18 & 0.10 & 0.02 & 1.38 \\
\hline & hospitals & 0.05 & 0.03 & 0.03 & 0.07 & 0.11 & 0.01 & 0.00 & 0.30 \\
\hline & restaurants & 0.01 & 0.02 & 0.02 & 0.00 & 0.02 & 0.02 & 0.00 & 0.10 \\
\hline & $\begin{array}{l}\text { shopping } \\
\text { centres }\end{array}$ & 0.05 & 0.08 & 0.00 & 0.07 & 0.10 & 0.00 & 0.00 & 0.30 \\
\hline & $\begin{array}{c}\text { supermark } \\
\text { ets }\end{array}$ & 0.02 & 0.12 & 0.50 & 0.00 & 0.26 & 0.02 & 0.00 & 0.92 \\
\hline \multirow{4}{*}{ Temperate } & hotels & 0.14 & 0.22 & 0.01 & 0.06 & 0.26 & 0.08 & 0.07 & 0.84 \\
\hline & offices & 0.02 & 0.10 & 0.00 & 0.06 & 0.06 & 0.00 & 0.00 & 0.25 \\
\hline & schools & 0.04 & 1.27 & 0.04 & 0.15 & 1.45 & 0.39 & 0.11 & 3.44 \\
\hline & hospitals & 0.04 & 0.10 & 0.10 & 0.08 & 0.58 & 0.03 & 0.01 & 0.94 \\
\hline
\end{tabular}




\begin{tabular}{ccccccccc} 
restaurants & 0.01 & 0.06 & 0.05 & 0.00 & 0.06 & 0.09 & 0.01 & $\mathbf{0 . 2 9}$ \\
$\begin{array}{c}\text { shopping } \\
\text { centres } \\
\begin{array}{c}\text { supermark } \\
\text { ets }\end{array}\end{array}$ & 0.04 & 0.22 & 0.00 & 0.17 & 0.34 & 0.00 & 0.00 & $\mathbf{0 . 7 7}$ \\
\hline Total [PJ] & $\mathbf{1 . 2 8}$ & $\mathbf{4 . 8 5}$ & $\mathbf{2 . 6 5}$ & $\mathbf{2 . 1 1}$ & $\mathbf{6 . 2 8}$ & $\mathbf{1 . 1 0}$ & $\mathbf{0 . 3 1}$ & $\mathbf{1 8 . 5 7}$
\end{tabular}

\subsection{Irreversibilities/Exergy destructions}

Exergy losses or irreversibilities by regions, end-uses and types of buildings were also estimated.

These values represent the true thermodynamic inefficiencies of the sector. This occurs mainly because electricity (a high grade source) is used in low-grade demands such as space conditioning or refrigeration; and gas in the case of water heating. Therefore these end-uses will naturally have low exergy efficiency values and high exergy destructions. Overall, the national exergy destruction is calculated to be in the order of $75.87 \mathrm{PJ}$ annually.

\subsubsection{By building}

At a national level, the largest destructions by type of building occur in schools, accounting for $46.8 \%$ of the total irreversibilities (35.48 PJ). Supermarkets and Hotels have a share of 20.0\% (15.16 PJ) and $13.0 \%(9.89 \mathrm{PJ})$ respectively. This is due to the fact that these buildings represent the largest percentage of floor area in the country. Fig. 7 shows the total exergy destruction percentage by building.

[Fig. 7. about here] 


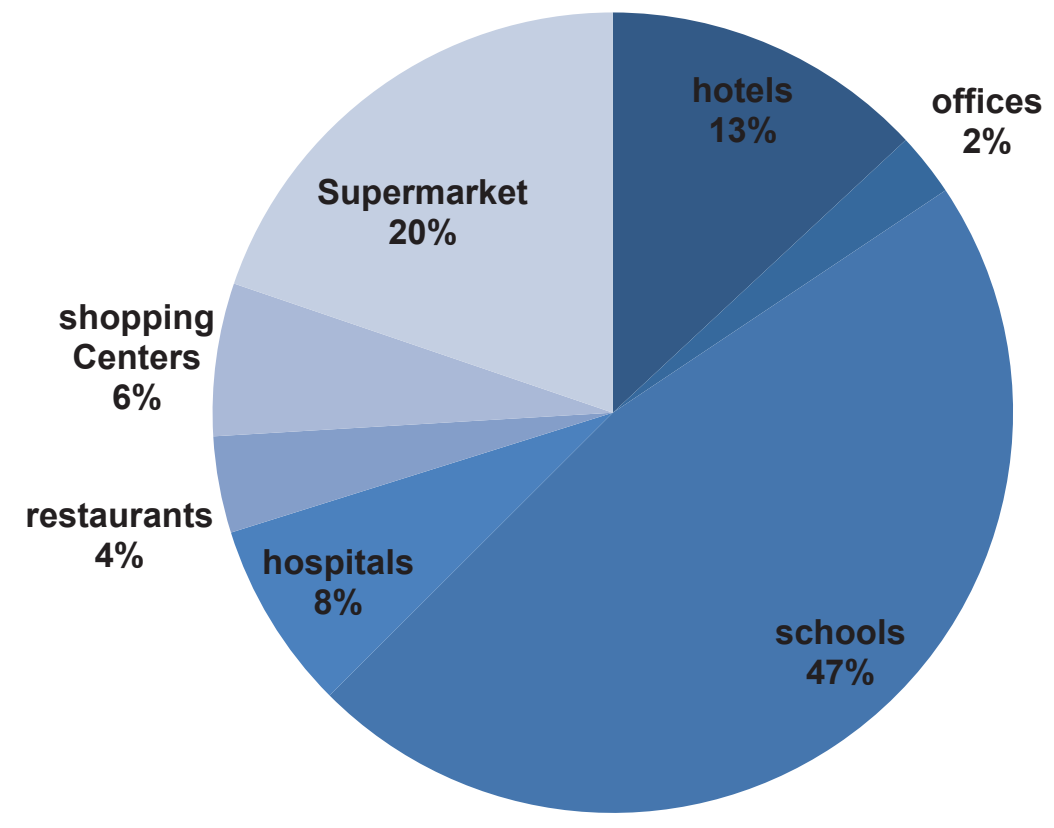

Fig. 7 Share of exergy destructions by building type in the Mexican non-domestic sector

\subsubsection{By climatic region}

The hot-dry and hot-humid regions combined have an exergy destruction in the order of 46.27 PJ, accounting for $61.1 \%$ of the total destruction in spite of this only representing less than half of the estimated total non-domestic floor area (43.9\%). The temperate region has destruction of around 29.44 PJ annually. Further detailed analysis of these results highlights that in the hot-dry region the largest exergy destruction is caused by HVAC systems, accounting for $40.5 \%$ (14.07 PJ) of the total regional destructions. Lighting also contributes a significant share, with a fifth of the regional destructions $(6.61 \mathrm{PJ})$. A similar trend can be observed in the hot-humid region, with $38.7 \%$ (8.39 PJ) and $20.1 \%$ (4.35 PJ) from HVAC and lighting systems respectively. Finally, in the temperate region the major destruction occur in lighting systems and accounts for $25.5 \%$ (9.96 PJ), while refrigeration and cooking systems account for $14.2 \%$ (5.55 PJ) and $13.4 \%(5.22 \mathrm{PJ})$ of the total regional destructions. Monthly regional exergy destructions can be seen in Figure 8.

[Fig.8. about here] 


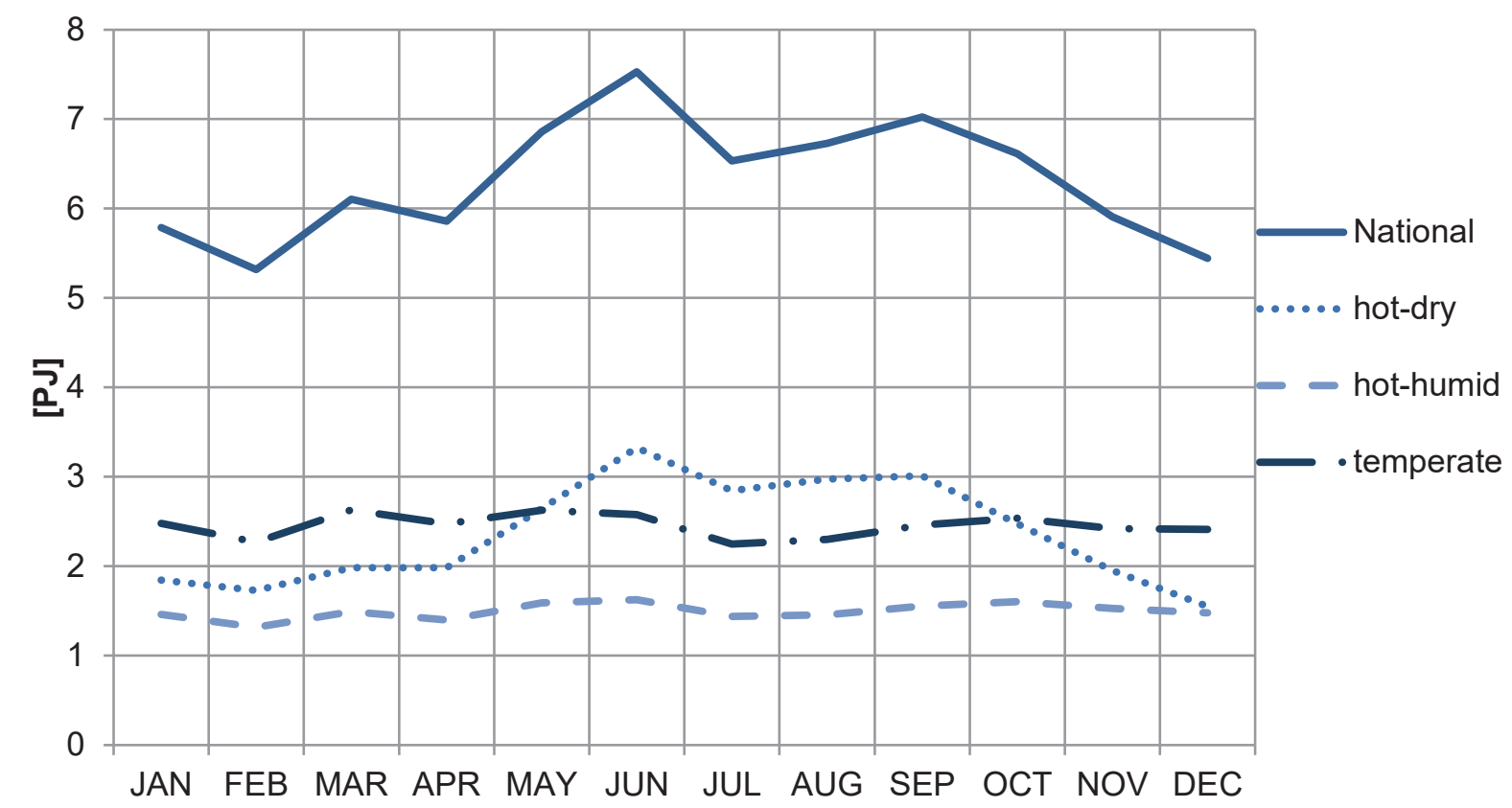

Fig. 8 Monthly exergy destructions of the Mexican non-domestic sector by climatic region

This analysis indicates that the temperate region and the hot-humid region have constant monthly destructions throughout the year. However, this is not the case for the hot-dry region, where a peak can be observed during the cooling season (May and October); even though the temperate region has more than half of the constructed $\mathrm{m}^{2}$, the hot dry region between these months has the largest destructions having a big impact on national exergy destructions.

\subsubsection{By end use}

From a national perspective the largest irreversibilities for end uses occur in HVAC and lighting systems with $35.4 \%$ (26.86 PJ) and $27.6 \%$ (20.91 PJ) respectively. For gas-based end uses, cooking represents $10.9 \%$ (8.18 PJ) of the total exergy destructions. The national exergy destruction share by end-use is illustrated in Fig. 9.

[Fig. 9. about here] 


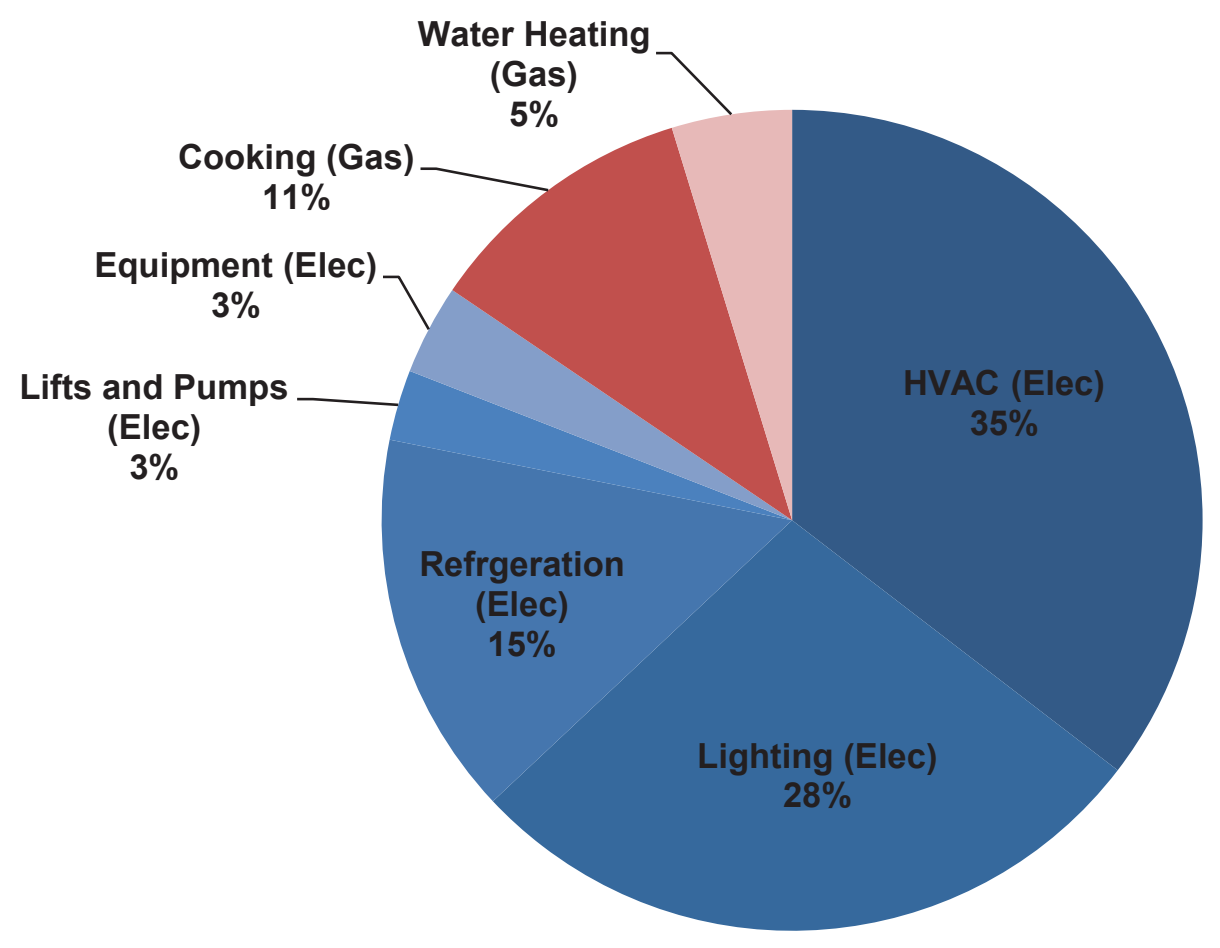

Fig. 9 Share of exergy destructions by end uses in the Mexican non-domestic sector

\subsubsection{Normalized exergy destruction}

Normalization of results allows the comparison of all the variables that may affect buildings and is considered a "perfect" metric to compare between similar buildings. Fig. 10 shows normalized exergy destruction by floor area $\left(\mathrm{MJ} / \mathrm{m}^{2}\right)$ at a region level and by end use. As it can be seen, depending on the building and the region, HVAC, refrigeration, and cooking have the largest destructions per square meter.

[Fig.10. about here] 


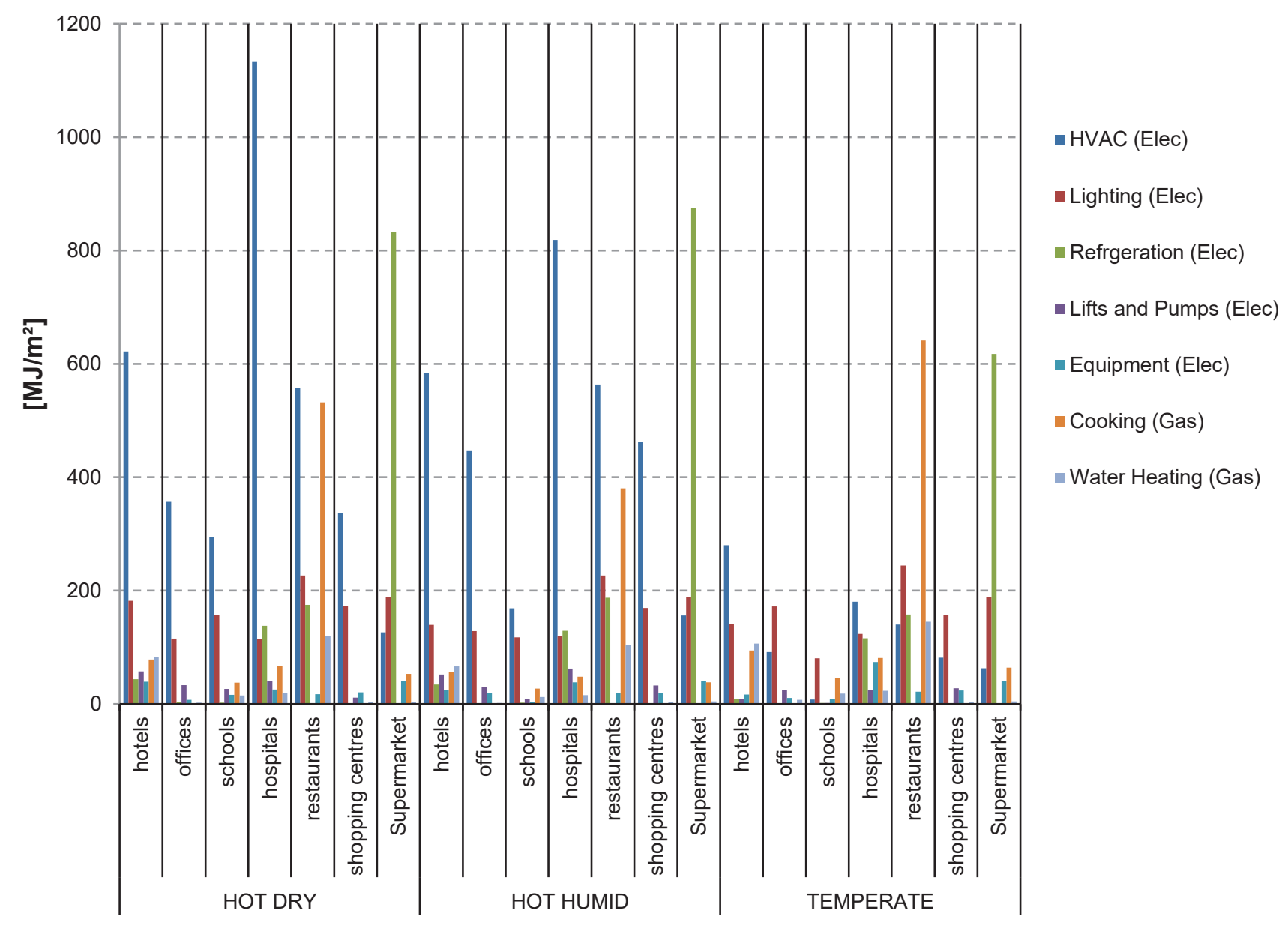

Fig. 10. Regional exergy destruction by floor area per type of building 4.4 Exergy efficiency by region and by building

\subsubsection{Regional efficiencies}

The monthly exergy efficiency is presented to illustrate the impact of fluctuating temperatures on exergy efficiency. The hot humid region and temperate region do not show significant fluctuations throughout the year. The hot-humid has a range of between $16.4 \%$ and $16.8 \%$ and the temperate region between $22.7 \%$ and $24.0 \%$. On the other hand, the hot-dry region is lowest at $14.8 \%$ in August and highest at $24.2 \%$ in December. The regional efficiencies throughout the year can be seen in Figure 11.

[Fig.11. about here] 


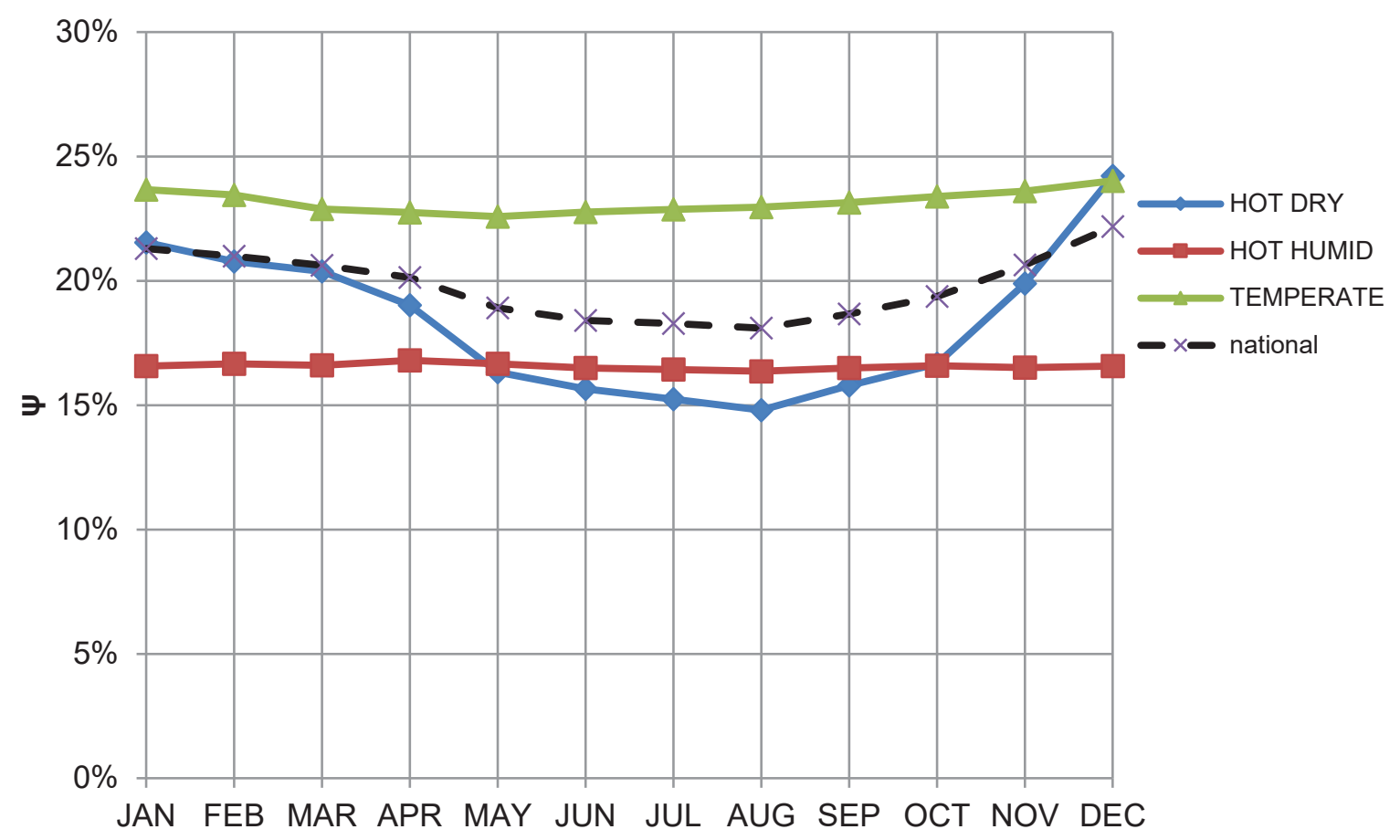

Fig. 11. Monthly exergy efficiency of the Mexican non-domestic sector by regions

\subsubsection{Efficiencies by building}

The highest exergy efficient building types highlighted by the model are hospitals and shopping centres located in the temperate climate with annual efficiencies of almost $30 \%$. This is due to the small share of space conditioning that this type of building uses in the temperate region; the great majority of buildings rely on natural ventilation unless the areas have high heat gains due to people and/or internal equipment. In the same region, hotels and restaurants exhibit low exergy efficiencies due to a larger demand of space conditioning, where thermal comfort standards are higher than in the other types of buildings analysed by the model. Therefore an intensive use of a high grade use to cover a low exergy demand (e.g. use of electricity for cooling) causes lower efficiencies. This behaviour is more noticeable by the buildings located in the hot-dry and hot-humid region, with exergy efficiencies no more than $18 \%$. Overall, these regions have lower efficiencies than the temperate region due to the high needs of cooling throughout the year where hospitals and restaurants have the lowest efficiencies of all analysed buildings, thus the largest irreversibilities by $\mathrm{m}^{2}$. The exergy efficiency by all types of buildings located in the analysed regions can be seen in Fig. 12 .

[Fig. 12. about here] 


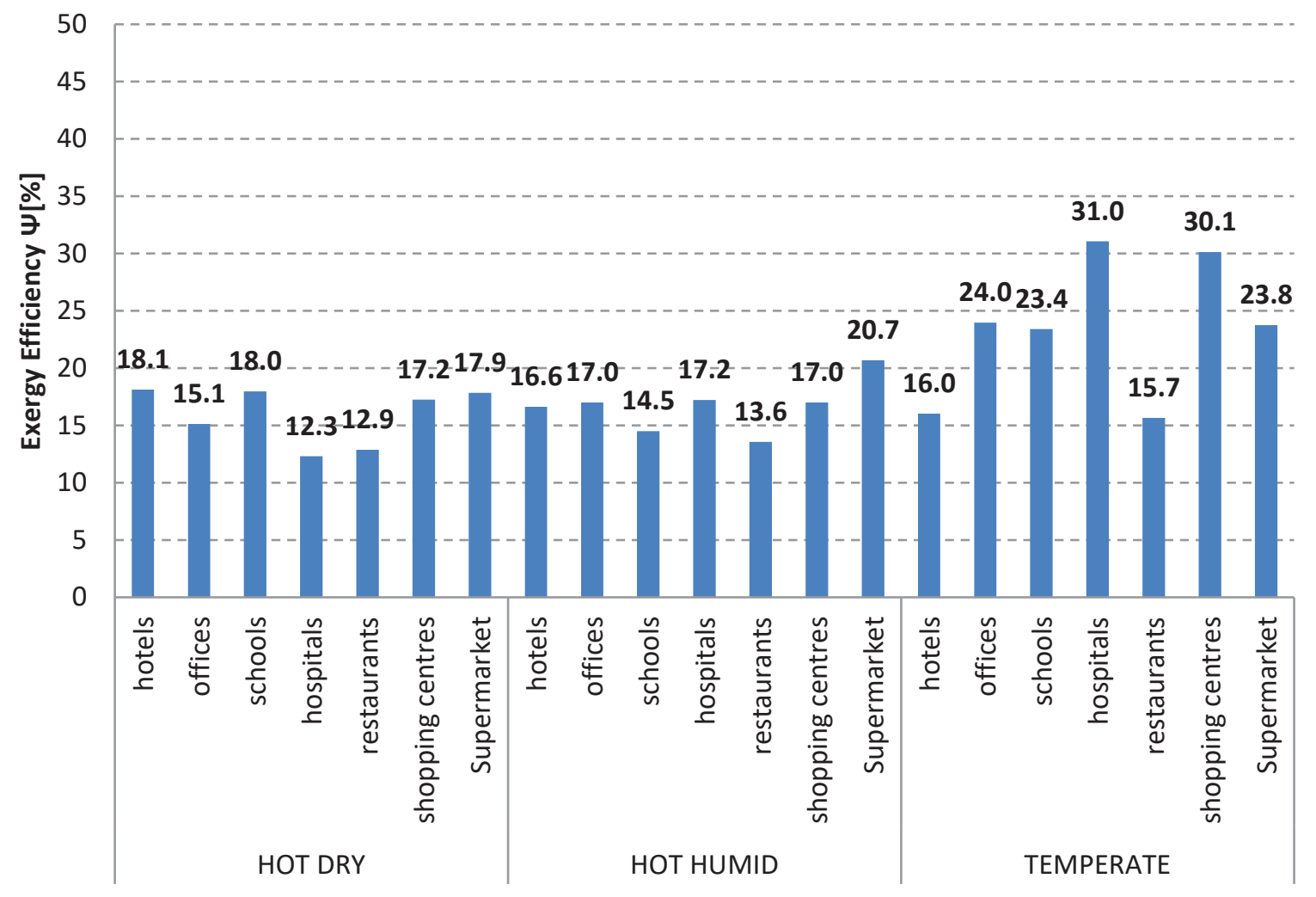

Fig. 12. Exergy efficiency by building in different climates of Mexico

As an end use, cooling has exergy efficiencies between $2.5 \%$ and $5.9 \%$. It can be considered a large amount of "energy consumption", but the reality is that the cooling needs of buildings can be met by low-grade sources, since the indoor temperatures usually range between $18-25^{\circ} \mathrm{C}$. In this sense, because of the low temperature level that it is needed to conditioning the buildings, the exergy demand is naturally low. In most cases, however, this demand is satisfied through high quality sources, such as fossil fuels or electricity (Schmidt, 2009). The typical HVAC systems located in the non-domestic buildings analysed are made such that these high-energy sources are delivering cooling at a low-grade $\left(\sim 14^{\circ} \mathrm{C}\right)$. This delivering temperature is low compared to the temperatures that high-grade energy sources can achieve $\left(\sim 1000^{\circ} \mathrm{C}\right)$, similar to the majority of the sources used in the Mexican building sector (electricity, natural gas and LPG). Therefore, the low exergy efficiency of the Mexican non-domestic sector is given by the ineffective match between the quality of the sources and the quality demand of the buildings. 
In summary, an exergy flow diagram (Fig 13) can be constructed for the Mexican non-domestic sector. This diagram sets out and clarifies the analysis undertaken in this paper and highlights the most important outcomes of the model.

[Fig. 13. about here]

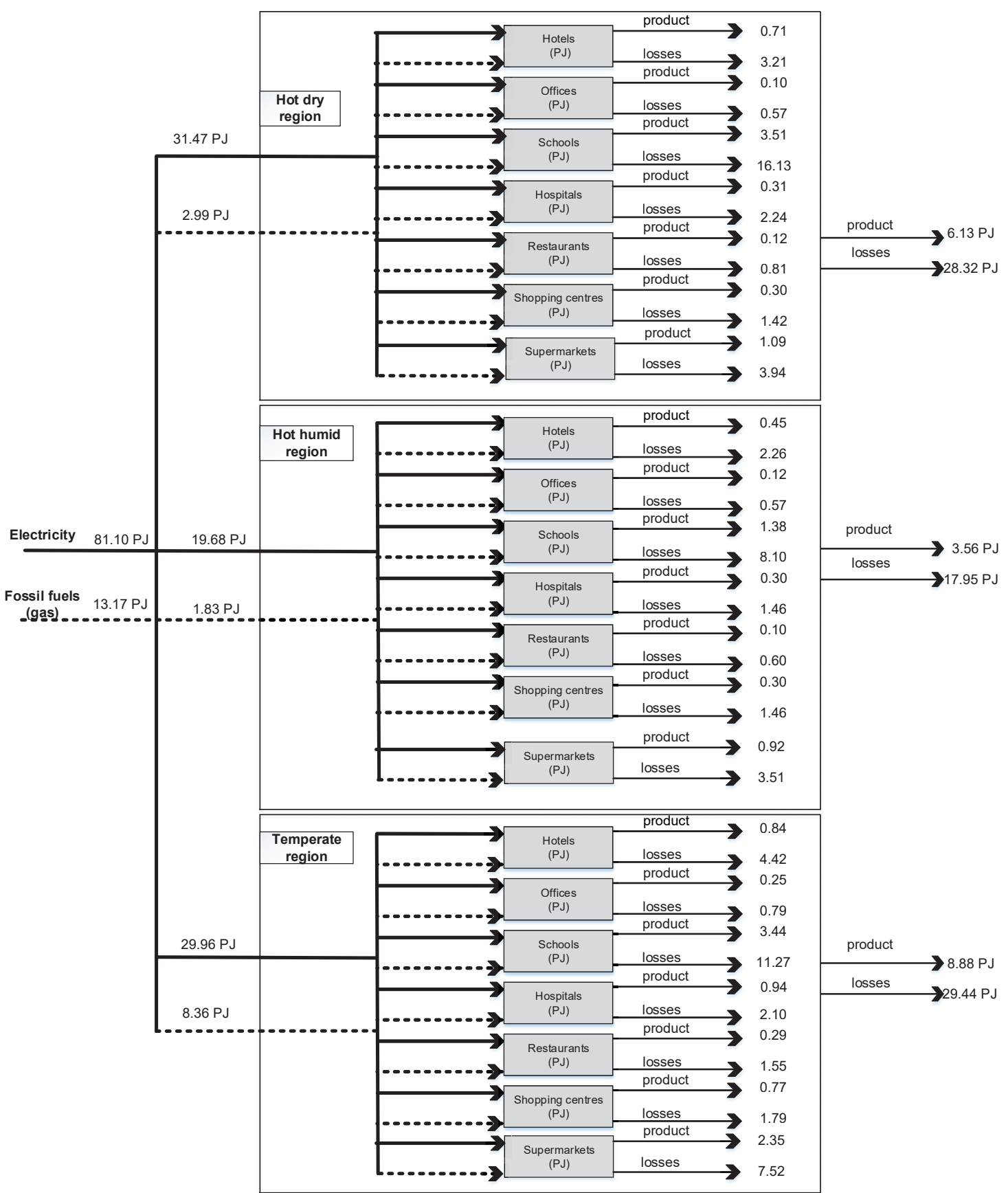

Fig. 13 "Exergy flows" diagram of the Mexican non-domestic sector

This exergy flow diagram also shows the exergy product and exergy destruction by region. These values represent the true thermodynamic efficiency of the regional sectors. According to these 
outputs, the non-domestic sector has an efficiency of $17.80 \%$ in the hot-dry region and $16.6 \%$ in the hot-humid region. These low efficiencies are caused by the extensive use of electricity for cooling. The non-domestic sector in the temperate region has an efficiency of $23.2 \%$, a very low value considering the bioclimatic benefits of this region where the potential to utilize passive systems such as natural ventilation and natural lighting is very high. Finally, the Mexican non-domestic as a whole has an exergy efficiency of $19.7 \%$.

\subsection{Comparison with other countries}

The national exergy indicators obtained were compared against some similar international indicators to analyze the main factors that influence the energy performance of buildings from several regions. From Table 13 it can be seen outputs from other sectoral exergy studies. The results for Mexico appear to have much higher efficiencies but this is due to two main reasons: a) the indicators from other studies are from past years (up to 30 years like in the case for Finland), and b) the mild climate located in Mexico has a high potential to use passive techniques such as natural ventilation and natural light, thus reducing exergy destructions. If the main analysis is based on the latter, it can be concluded that the exergy efficiency of the Mexican non-domestic sector is actually very low. Because of the colder climates in countries such as Japan, Canada, Sweden, US and the UK, high energy inputs for heating is required, an end-use with typical low exergy efficiency due to the use of high grade sources like natural gas or electricity to cover this demand. Countries with higher indicators are due to the utilization of low carbon sources such as the implementation of heat waste district systems, as in the case of Norway and Canada. In hot countries such as Brazil, Malaysia, Indonesia and Singapore, present lower efficiencies than Mexico because space conditioning represents more than half of the total energy use in the sector (in Mexico, space conditioning only represents $29.5 \%$ of the total energy utilisation). Higher efficiencies in these countries could be achieved from two approaches:

a) passive improvements by using natural ventilation and/or b) a more extensive use "low carbon" technologies such as heat pumps, CHP, and/or district cooling networks.

[Table 13 about here]

Table 13 International non-domestic sector exergy efficiencies

\begin{tabular}{cccc} 
Country & $\psi$ & year & Source \\
\hline Mexico & $19.7 \%$ & 2014 & \\
Mexico hot-dry & $17.8 \%$ & 2014 &
\end{tabular}




\begin{tabular}{|c|c|c|c|}
\hline Mexico hot-humid & $16.6 \%$ & 2014 & \\
\hline Mexico temperate & $23.2 \%$ & 2014 & \\
\hline Japan & $5.8 \%$ & 2009 & (Kondo, 2009) \\
\hline Canada* & $14.0 \%$ & 1986 & (Rosen, 2013) \\
\hline Ontario* & $21.0 \%$ & 1986 & (Rosen, 2013) \\
\hline Norway* & $11.0 \%$ & 1995 & (Ertesvåg, 2001) \\
\hline Sweden* & $13.0 \%$ & 1994 & (Ertesvåg, 2001) \\
\hline Italy* & $2.0 \%$ & 1990 & (Ertesvåg, 2001) \\
\hline Turkey* & $6.0 \%$ & 1995 & (Ertesvåg, 2001) \\
\hline Brazil* $^{*}$ & $12.0 \%$ & 1987 & (Ertesvåg, 2001) \\
\hline Finland* & $8.0 \%$ & 1985 & (Ertesvåg, 2001) \\
\hline USA $^{*}$ & $14.0 \%$ & 1970 & (Reistad Gordon, 1980) \\
\hline Turkey* & $8.9 \%$ & 2001 & (Utlu and Hepbasli, 2003) \\
\hline Saudi Arabia & $8.1 \%$ & 2001 & (Dincer et al., 2004) \\
\hline Malaysia & $4.3 \%$ & 1999 & (Saidur et al., 2007) \\
\hline Singapore & $3.4 \%$ & 1999 & (Saidur et al., 2007) \\
\hline Thailand & $7.5 \%$ & 1999 & (Saidur et al., 2007) \\
\hline Indonesia & $4.8 \%$ & 1999 & (Saidur et al., 2007) \\
\hline UK & $12.3 \%$ & 2004 & (Gasparatos et al., 2009) \\
\hline
\end{tabular}

\section{Policy Implications}

The disaggregation of the energy use and exergy destructions by region, buildings and end-uses, allows for a more straightforward identification process regarding where policy and programs should focus. The energy usage indicators (EUI) presented represents a powerful tool for the smart deployment of efficiency measures. The granularity that is presented may enhance the development of more targeted energy efficiency programs. As a first step to achieving a sustainable building sector, local governments should adopt benchmarking and disclosure requirements for all nondomestic buildings. In addition, exergy benchmark (especially for space conditioning process in hot climates) may help in the thermodynamic optimization of these systems.

Despite the efforts made in the last decades to reduce energy use in the Mexican non-domestic sector, it is still necessary to reduce the energy use of common processes in existing buildings, with particular focus on cooling, lighting, refrigeration and water heating. The theoretical background to this work suggests that only performing energy analysis can be misdirecting. For example, current regulations estimate that cooling services are very efficient in energy terms (hypothetically $>100 \%$ ), but the model used in this study showed that the exergy efficiency is regularly lower than $10 \%$. In 
some regions depending on the month, this can get closer to $1 \%$. The same behavior can be found in water heating processes. A limitation of current regulations is that they are only based on the First Law of thermodynamics; therefore the addition of exergy to the policy-making process may provide an effective tool to improve resource utilisation, energy conservation, and energy security in the country. Exergy could become a key indicator for more sustainable buildings which may lead to the smarter deployment of resources and an increased focus on more optimized energy building systems.

Public programs should focus on areas where more potential for improvements can be achieved. As a result of the monthly analysis of exergy destructions and exergy efficiency, the main focus of these policies should include buildings in the hot-dry climate, where total irreversibilities account for the same amount as in the temperate region in spite of having less than half of the constructed surface. Furthermore, some potential does exist for the implementation of a mixed approach between active and passive systems refurbishments such as mechanical/natural ventilation systems. Additionally, urban areas in this region have high development rates, therefore preventive policies should be applied to new buildings. For the temperate region, the deployment of passive strategies such as natural ventilation, natural lighting and solar water heating can greatly improve the regional efficiency and should be the focus of local programs. The hot-humid region presents a great challenge, especially for the constant cooling demand of the buildings. In order to bring the quality of the fuels closer to the quality demanded by some end-uses, more policies and incentives are needed to support technologies that work with low-quality sources. Consequently, to increase the exergy efficiency in cooling in all regions, the creation of programs that could encourage the deployment of low carbon technologies such as heat pumps, CHP with absorption chillers, and the development of district cooling networks combined with bioclimatic strategies should be implemented. Furthermore, the development of codes to set minimum envelope requirements is needed to lower the space cooling demands.

Finally, policies should encourage the development and implementation of an energy/exergy directive applied to Mexican buildings. Exergy indicators should be mandatory when reduction strategies are assessed to gain a clearer picture of the potential improvements. Although more research is needed on the subject, exergy indicators can be also used to apply penalties to buildings with low efficiencies.

\section{Conclusion}


This study presented the development of an archetype-based bottom-up building energy model supported with an exergy method developed by Dincer et al. (2004) to assess the energy/exergy utilization of the Mexican non-domestic sector. The analysis was undertaken based on very detailed database of 120 non-domestic buildings located in different regions of the country. First law or energy analysis was implemented to give a first insight into a sector that lacks detailed energy information. The methodology for the development of a stock model implemented for this study could serve as a basis for other similar studies, especially those were data is limited and several assumptions have to be made. On the other hand, the exergy approach was included in the model to identify locations and magnitudes of exergy destructions. In extending the work undertaken in similar research, it is the first time that energy and exergy stock model has been developed through the use of archetype buildings and building physics modelling with the potential to undertake the modelling of future refurbishment programs based on exergy improvements. Furthermore, the exergy model developed in this research can be an essential method for policy making and national standard design activities

According to the Mexican model, the non-domestic sector demands 95.43 PJ of energy and 94.28 PJ of exergy. These inputs are mainly used for space conditioning, lighting, refrigeration, and cooking. Also, it was possible to quantify the impact of local climate at end-uses, buildings, and regions. It is concluded that Mexican climatic conditions have a large impact on the exergy efficiency in the sector. Regionally, the exergy efficiencies found was in the order of $17.8 \%, 16.6 \%$, and $23.2 \%$ for the hot-dry, hot-humid, and temperate climate respectively. The national exergy efficiency of the sector was found to be $19.7 \%$ with an output of $18.41 \mathrm{PJ}$ and exergy destructions of $75.87 \mathrm{PJ}$. On the other hand, the overall energy efficiency of the sector was calculated at $66.4 \%$. A large difference exists because of the use of high quality sources for low quality demands. The use of high-grade sources for low-grade demands in buildings is still a constant in our societies and should be a major concern for the world energy security. Until today, all Mexican sectors are highly dependent on high-grade fuels.

The classification by end-use presented in this paper allows us for a deeper understanding of the energy and exergy utilization of the sector. A high potential of decarbonizing the Mexican building sector exist, especially in hot climates. This outcomes will help the policy makers to identify where the main destructions occur and what kind of policies should be focus on reduce this inefficiencies. The model showed that the main irreversibilities occur at the HVAC systems; therefore special attention 
has to be put in this area. By following the exergy concept, the total $\mathrm{CO}_{2}$ emissions for the building stock can be substantially reduced as a result of the use of more efficient energy conversion processes. Exergy have the benefit of utilizing resources in a smarter way, and try to put more attention in the efficient use of renewable energy and the development of bioclimatic design strategies for buildings that eventually would lead to an increase of the energy/exergy efficiency of the Mexican building sectors.

\section{Future work}

It is important to note that since the modelling methodology presented is still under development and further improvements are intended, this includes:

- Undertaking of in-depth analysis to ground the archetype models in more robust data: This will include the collection of more defined data on a number of buildings, floor area and installed energy systems to improve the model.

- Extension of building types covered: More detailed specification of non-domestic building subtypes.

- Development of a retrofit module: This will be included to explore the future technical potential of different refurbishment strategies and identify the impact on national building sustainability under energetic and exergetic indicators.

- Further research to quantify the benefits of passive measures and low exergy systems at a regional level in Mexico.

As this model is considered to be useful in the evaluation of a single subsector or a whole building sector energy and exergy performance, the application of the modelling framework to other countries is currently being investigated. An analysis of the UK non-domestic sector is currently under way with the intention of investigating the current performance of the sector and modelling the impact of different refurbishment measures based on exergetic terms.

\section{Acknowledgments}

The author of this paper acknowledges support from The Mexican National Council for Science and Technology (CONACyT) through a scholarship to pursue graduate studies. Also, we want to thank FIDE for sharing information and data from audit case studies in Mexican non-domestic buildings. 
Finally, we would like to thank the reviewers for their insightful comments on the paper, as these comments led us to an improvement of the work.

\section{References}

Al-Ghandoor, A., 2013. Evaluation of energy use in Jordan using energy and exergy analyses. Energy and Buildings 59, 1-10.

ASHRAE. (1977). ASHRAE 1977 Handbook: Fundamentals, U.S.A.

ASHRAE. (2010). ASHRAE 90.1 Appendix G: Building Performance Rating Method, U.S.A.

Asif, M., Muneer, T., 2007. Energy supply, its demand and security issues for developed and emerging economies. Renewable and Sustainable Energy Reviews 11, 1388-1413.

Aydinalp, M., Ugursal, V.I., Fung, A.S., 2003. Modelling of residential energy consumption at the national level. INTERNATIONAL JOURNAL OF ENERGY RESEARCH 27, 441-453.

Bilgen, E., Takahashi, H., 2002. Exergy analysis and experimental study of heat pump systems. Exergy, An International Journal 2, 259-265.

Bressani, R., Chon, C., 1996. Effects of altitude above sea level on the cooking time and nutritional value of common beans. Plant foods for human nutrition (Dordrecht, Netherlands) 49, 53-61.

Bruhns, H., 2007. Identifying Determinants of Energy Use in the UK nondomestic Stock. Bartlett School of Graduate Studies, University College London, London, United Kingdom.

CONAGUA. 2014., Normales Climatológicas por Estación . Accessed: 26 April 2014, url: http://smn.cna.gob.mx/.

CONNUE, 2013. La importancia de los edificios del sector comercial y de servicios como usuarios de electricidad y las estrategias para la eficiencia energética, Presentation by Odon de Buen, March 2013.

Daft Logic. (2014). Google Maps Area Calculator Tool [Online]. Map of Mexico, retrieved on Jan $20^{\text {th }}$, 2014. url: http://www.daftlogic.com/projects-google-maps-area-calculator-tool.htm 
de Buen, O., 2009. Greenhouse Gas Emission Baselines and Reduction Potentials from Buildings in Mexico: A Discussion Document, in: SBCI, U. (Ed.), France.

Deru, M., Field, K., Studer, D., Benne, K., Griffith, B., Torcellini, P., Liu, B., 2011. U.S. Department of Energy Commercial Reference Building Models of the National Building Stock. Technical Report NREL/TP-5500-46861, 118.

Dincer, I., 2002. The role of exergy in energy policy making. Energy Policy 30, 137-149.

Dincer, I., Hussain, M.M., Al-Zaharnah, I., 2004. Analysis of sectoral energy and exergy use of Saudi Arabia. International Journal of Energy Research 28, 205-243.

Dineen, D., Gallachoir, B.P.O., 2011. Modelling the impacts of building regulations and a property bubble on residential space and water heating. Energy and Buildings 43, 166-178.

Dovjak, M., Shukuya, M., Olesen, B.W., Krainer, A., 2010. Analysis on exergy consumption patterns for space heating in Slovenian buildings. Energy Policy 38, 2998-3007.

ECB-Annex37, 2007. Technical Synthesis Report: Low Exergy Systems for Heating and Cooling of Buildings, IEA ECBCS, in: Jagpal, R. (Ed.), UK.

ECB-Annex49, 2011. Detailed Exergy Assessment Guidebook for the Built Environment, IEA ECBCS, in: Torio, H., Schmidt, D. (Eds.). Fraunhofer IBP.

EnergyPlus, 2012. Getting Started with EnergyPlus. BasicConcepts Manual - Essential Information You Need about Running EnergyPlus. The Board of Trustees of the University of Illinois and the Regents of the University of California through the Ernest Orlando Lawrence Berkeley National Laboratory., 73.

Ertesvåg, I.S., 2001. Society exergy analysis: a comparison of different societies. Energy 26, 253270.

Famuyibo, A.A., Duffy, A., Strachan, P., 2012. Developing archetypes for domestic dwellings-An Irish case study. Energy and Buildings 50, 150-157.

FIDE, 2011. Proyectos de Ahorro de Energia. Casos de Estudio. Fideicomiso para el Ahorro de Energia Electrica, Mexico, D.F. 
Gallo, W.L.R., Milanez, L.F., 1990. Choice of a reference state for exergetic analysis. Energy 15, 113121.

Gasparatos, A., El-Haram, M., Horner, M., 2009. Assessing the sustainability of the UK society using thermodynamic concepts: Part 2. Renewable and Sustainable Energy Reviews 13, 956-970.

Griffith, B., Crawley, D., 2006. Methodology for Analyzing the Technical Potential for Energy Performance in the U.S. Commercial Buildings Sector with Detailed Energy Modeling. Conference Paper NREL/CP-550-40124, 10.

Google. (2014). Google Maps. [Online], Map of Mexico, retrieved on Feb 2nd, 2014, url: http://maps.google.com.mx

Hammond, G.P., Stapleton, A.J., 2001. Exergy analysis of the United Kingdom energy system. Proceedings of the Institution of Mechanical Engineers, Part A: Journal of Power and Energy 215, $141-162$.

Hepbasli, A., 2012. Low exergy (LowEx) heating and cooling systems for sustainable buildings and societies. Renewable and Sustainable Energy Reviews 16, 73-104.

Huang, Y.J., Broderick, J., 2000. A Bottom-Up Engineering Estimate of the Aggregate Heating and Cooling Loads of the Entire U.S. Building Stock. ACEEE Summer Study on Energy Efficiency in Buildings, 135-148.

INEGI, Accessed: 20 April 2014. Poblacion, Hogares y Vivienda, url: http://www3.inegi.org.mx/sistemas/temas/default.aspx?s=est\&c=17484.

IPCC, 2007. Climate Change 2007: Mitigation of Climate Change. Contribution of Working Group III to the Fourth Assessment Report of the Intergovernmental Panel on Climate Change.

Kondo, K., 2009. Energy and exergy utilization efficiencies in the Japanese residential/commercial sectors. Energy Policy 37, 3475-3483.

Korolija, I., Marjanovic-Halburd, L., Zhang, Y., Hanby, V.I., 2013. UK office buildings archetypal model as methodological approach in development of regression models for predicting building energy consumption from heating and cooling demands. Energy and Buildings 60, 152-162. 
Reistad Gordon, M., 1980. Available-Energy Utilization in the United States, Thermodynamics: Second Law Analysis. AMERICAN CHEMICAL SOCIETY, pp. 93-109.

Rosen, M., 2013. Using Exergy to Assess Regional and National Energy Utilization: A Comparative Review. Arab J Sci Eng 38, 251-261.

Rosen, M., Bulucea, C.A., 2009. Using Exergy to Understand and Improve the Efficiency of Electrical Power Technologies. Entropy 11, 820-835.

Rosen, M.A., 1992. Evaluation of energy utilization efficiency in Canada using energy and exergy analyses. Energy 17, 339-350.

Sadorsky, P., 2009. Renewable energy consumption and income in emerging economies. Energy Policy 37, 4021-4028.

Saidur, R., Sattar, M.A., Masjuki, H.H., Abdessalam, H., Shahruan, B.S., 2007. Energy and exergy analysis at the utility and commercial sectors of Malaysia. Energy Policy 35, 1956-1966.

Schmidt, D., 2009. Low exergy systems for high-performance buildings and communities. Energy and Buildings 41, 331-336.

SENER, 2001. NOM-008-ENER-2001, Eficiencia energética en edificaciones, envolventes de edificios no residenciales., Mexico, D.F.

SENER, 2005a. NOM-007-ENER-2004, Eficiencia energética en sistemas de alumbrado en edificios no residenciales., Mexico, D.F.

SENER, 2005b. NOM-014-ENER-2005, Eficiencia energética de motores de corriente alterna, monofásicos, de inducción, tipo jaula de ardilla, enfriados con aire, en potencia nominal de 0,180 a 1,500 KW. Límites, método de prueba y marcado., Mexico, D.F.

SENER, 2007. NOM-011-ENER-2006, Eficiencia energética en acondicionadores de aire tipo central paquete o dividido. Límite, métodos de prueba y etiquetado., Mexico, D.F.

SENER, 2008. NOM-022-ENER/SCFI-2008, Eficiencia energética y requisitos de seguridad al usuario para aparatos de refrigeración comercial autocontenidos. Límites, métodos de prueba y etiquetado., Mexico, D.F. 
SENER, 2011. NOM-003-ENER-2011, Eficiencia térmica de calentadores de agua para uso doméstico y comercial. Límites, método de prueba y etiquetado., Mexico, D.F.

SENER, 2013. Balance Nacional de Energía 2012, Mexico, D.F.

Shukuya, M., 1994. Energy, Entropy, Exergy and Space Heating Systems, in: Bánhidi, L. (Ed.), Healthy Buildings '94: proceedings of the 3rd international conference. Technical University of Budapest, pp. 369-374.

Swan, L.G., Ugursal, V.I., 2009. Modeling of end-use energy consumption in the residential sector: A review of modeling techniques. Renewable and Sustainable Energy Reviews 13, 1819-1835.

UNEP-SBCI, 2009. Buildings and Climate Change Summary for Decision-Makers. UNEP Sustainable Buildings \& Climate Initiative.

Utlu, Z., Hepbasli, A., 2003. A study on the evaluation of energy utilization efficiency in the Turkish residential-commercial sector using energy and exergy analyses. Energy and Buildings 35, 11451153.

Xydis, G., Koroneos, C., Polyzakis, A., 2009. Energy and exergy analysis of the Greek hotel sector: An application. Energy and Buildings 41, 402-406. 